\title{
Homology and morphology in Poduromorpha (Hexapoda, Collembola)
}

\author{
Cyrille A. D'HAESE
}

\begin{abstract}
FRE 2695 CNRS, Laboratoire d'Entomologie, Museum National d'Histoire Naturelle, 45 rue Buffon, F-75005 Paris, France
Division of Invertebrate Zoology, American Museum of Natural History, Central Park West at 79th St, New York, NY 10024, USA; e-mail: dhaese@mnhn.fr
\end{abstract}

Key words. Chaetotaxy, Poduromorpha, Entomobryomorpha, Symphypleona, Neelipleona, neoteny, homology, phylogeny, postembryonic development

\begin{abstract}
The detailed external morphology and general anatomy of the majority of families and subfamilies of Poduromorpha were investigated and compared. This examination was done in relation to the three remaining orders of Collembola: Entomobryomorpha, Symphypleona and Neelipleona. Within Poduromorpha, homologies among the different families and subfamilies are established for general chaetotaxy, and chaeotaxy of head, buccal cone, sensilla of fourth antennal segment, anal valves and tibiotarsus. A consistent and comprehensive nomenclature is proposed for these morphological features unifying those applied in scattered existing studies. Observations on first instars are reported. Comparison of first instars and adult chaetotaxy suggests a possible paedomorphic trend in the evolution of Poduromorpha.
\end{abstract}

\section{INTRODUCTION}

The external anatomy of springtails (class Collembola) has been investigated for a long time (e.g., Bourlet, 1839; De Geer, 1743; Lubbock, 1873), starting consistently with the work of Börner (e.g., Börner, 1901, 1906, 1913). Since then, our knowledge of springtail morphology has increased significantly. However, most studies have focused on single groups of different levels: Subfamily (e.g., Rusek, 1976), genus (e.g., Yosii, 1962) or even a single species (e.g., André, 1988). Almost no attempts have been made to generalize to the other groups, with the exception of a comprehensive work on the labial palps (Fjellberg, 1999). Consequently, several nomenclatures exist for the same structures according to different groups and usually the homologies have not been clarified.

The main goal of the present work is to establish homologies of the morphological features among the different groups in Poduromorpha, and to do this in relation to the other orders when possible. It is also my intention to provide a comprehensive nomenclature unifying the scattered and incomplete studies available in the literature.

Springtails are a diverse group with more than 6500 species described to date (Rusek, 1998), This probably represents a small part of their total specific diversity, a diversity that could reach more than 50000 species (Hopkin, 1997; Hopkin, 1998). Poduromorpha comprises more than a third of the described species of springtails with about 2500 species in approximately 260 genera.

The class Collembola is traditionally divided in two groups (e.g. Börner, 1906; Cassagnau, 1990; Gisin, 1960; Hopkin, 1997; Massoud, 1971b; Uchida, 1971), Arthropleona and Symphypleona sensu lato. The Symphypleona s.l. are comprised of the orders Symphypleona sensu stricto and Neelipleona. Members of this group are globular in shape with fused abdominal segments. Arthro- pleona are characterized by possession of an elongate body with abdominal segments $1-4$ clearly separated from each other by an intersegmental membrane. Arthropleona is comprised of the orders Poduromorpha and Entomobryomorpha. The Poduromorpha have a distinct prothorax that bears dorsal setae and third and fourth abdominal segments that are similar in size. Generally Entomobryomorpha have a greatly reduced prothorax that never bears setae, as in Symphypleona s.1., and the fourth abdominal segment is two to four times longer than the third segment. Exceptions to this are Isotomidae, Oncopoduridae and Tomoceridae, which have similar sized abdominal segments as in Poduromorpha.

\section{MATERIAL AND METHODS}

To carry out the present study, the collections of the Muséum National d'Histoire Naturelle (MNHN, France) were studied as well as institutional loans and personal field collecting. Thirteen species covering the diversity of Poduromorpha were also kept in culture for several years in order to study first instars and postembryonic development: Tetrodontophora bielanensis Waga, 1842 (Tetrodontophorinae), Onychiurus ambulans Linné, 1758, Kalaphorura paradoxa Schäffer, 1900, and Protaphorura armata Tullberg, 1869 (Onychiurinae), Mesaphorura macrocheta Rusek, 1976 (Tullbergiinae), Ceratophysella gibbosa (Bagnall, 1940) and Xenylla tullbergi Börner, 1903 (Hypogastruridae), Podura aquatica Linné, 1758 (Poduridae), Friesea mirabilis (Tullberg, 1871) (Frieseinae), Amurida granaria (Nicolet, 1847) (Pseudachorutinae), Morulina verrucosa Börner, 1903 (Morulinae), Monobella grassei Denis, 1923 and Neanura muscorum Templeton, 1835 (Neanurinae) and an Entomobryomorpha, Folsomia candida Bourlet, 1839 (Isotomidae). In total, more than one hundred species were examined for this study. These species represent all families and subfamilies of Poduromorpha and some major groups in the three remaining orders (Entomobryomorpha, Symphypleona, and Neelipleona).

Specimens were preserved in 95\% ethyl alcohol; dissections of mouthparts and other structural features were made in that medium. They were cleared in successive $10 \%$ potassium 
hydroxide solution and Amann's Lactophenol (lactic acidglycerol-phenol: 25-50-25). The Lactophenol medium was slightly warmed up for the most pigmented specimens. Specimens were mounted on microscope slides using Marc André II mounting medium (see Massoud, 1967). The slides were slightly warmed up with an alcohol burner in order to improve specimen position in the slide for a favorable observation (slight inflation).

Specimens were examined using a compound microscope with differential interference contrast optics at magnifications ranging form 250 to 1250 (oil immersion lens for the higher magnifications). Drawings were made with a drawing tube.

\section{RESULTS}

\section{General aspects}

Poduromorpha are elongate springtails with a clearly segmented body, cylindrical in shape or slightly flattened. Contrary to other springtails, the prothorax is always developed and bears dorsal setae. Members of this group are generally small, with some species as small as $0.4 \mathrm{~mm}$ in length (e.g. in the genera Mesaphorura Börner, 1901 and Willemia Börner, 1901). However, some species can grow to a centimeter in length (e.g. in the genera Tetrodontophora, Holacanthella Börner, and Caledonimeria Delamare Deboutteville \& Massoud, 1962).

Poduromorpha are usually uniformly pigmented: many are white (Onychiurinae, Tullbergiinae, Willemia, some Anurida Laboulbène, 1865 etc.) while most of the others present a monochromatic pigmentation limited to blue or red. The degree of pigmentation is correlated to latitude and altitude; the number of dark species increases near the poles and in mountains (Rapoport, 1969). Rapoport (1971) considered that the darker species warm up more quickly in the sun and are more active than the lighter colored species. However, dark species are actually found on sun-exposed places as the littoral seashore (e.g. the dark-blue Anurida maritima (Guérin-Méneville, 1836), and the dark Actaletidae) and several studies showed that Collembola were sensitive to UV radiation and suggested that dark pigmentation plays a protective role in exposed species (Verhoef et al., 2000; Zinkler \& Wilking, 1989). Species with patterns of different colors are exceptional: there are a few bi-colored species that are usually dark blue and yellow (Arlé \& Rufino, 1976; Mendoça \& Fernandes, 1999), occasionally red and yellow or rarely tricolored red, yellow and white (Cassagnau \& Deharveng, 1984). More generally, pigmentation in Poduromorpha is much more uniform than in Entomobryomorpha and Symphypleona. However, knowledge on pigmentation of Collembola remains very fragmentary insofar as it has not been studied extensively (e.g. Bouthier \& Thibaud, 1974).

Cuticle. Examination of the surface of the cuticle using a scanning electron microscope indicates a characteristic granulation (Dallai, 1973; Lawrence \& Massoud, 1974; Massoud, 1969; Massoud \& Barra, 1980; Massoud \& Betsch, 1973). The ornamentation of the cuticle presents mainly three degrees of complexity:

1. Primary granules: elementary granules, generally triangle-shaped, that are regularly distributed and linked to one another by ridges and thus forming a hexagonal pattern (Massoud, 1969). Sometimes, these elementary granules are square-shaped, resulting in a squared pattern (as in Podura aquatica);

2. Secondary granules: one or several of the primary granules are deformed and enlarged to form protuberances (Dallai, 1973; Hale \& Smith, 1966). Secondary granules are found in Poduromorpha and Symphypleona but not in Entomobryomorpha (Massoud, 1969; Massoud \& Thibaud, 1979);

3. Tertiary granules: the grouping of several secondary granules forms the tertiary granules characteristic of Neanurinae (Deharveng, 1983). The tubercles are a result of the tertiary granules structure deforming the cuticle. Tetrodontophora bielanensis also possess tertiary granules that resemble "pseudo-scales" (Massoud \& Betsch, 1973). However, this structure is not homologous to the tubercles found in Neanurinae.

The integument forms hypodermic reticulation in some taxa, for example in the genera Gulgastrura Yosii, 1966 (Lee \& Thibaud, 1987), Willemia (D'Haese \& Weiner, 1998), Caputanurina Lee, 1983 (Najt \& Weiner, 1992), many species of Neanurinae (Deharveng, 1983; Massoud, 1967), in Morulinae (Stach, 1951), and also in some Entomobryomorpha as in the genera Jestella Najt, 1977 (Najt, 1977), and Tetracanthella Schött, 1891 (Deharveng, 1987). These reticulations are caused by the presence of a superficial endoskeleton (Cassagnau \& Lauga-Reyrel, 1984).

The integument can fold, forming digitations and bumps. Some species of Neanuridae were grouped in Uchidanurinae on this criterion alone (Cassagnau, 1980). However, digitations are found in other groups, for example in the genus Probolaphorura Dunger, 1976 (Onychiurinae) (Dunger, 1976).

Pseudocelli. Onychiuridae possess characteristic cuticular structures known as pseudocelli, which are unique to this group. Three main types of pseudocelli were defined (Rusek, 1984; Rusek \& Weyda, 1981):

1. Simple pseudocelli are found in Tullbergiinae. The pseudocellar lid is weakly separated from the integument and weakly differentiated into one or a few flaps arranged into a rosette or tangentially. The granulation of the pseudocelli is a primary granulation or is the same as the surrounding integument (Rusek \& Weyda, 1981). These pseudocelli are big in comparison to the other types of pseudocelli; In Tullbergiinae, pseudocelli were classified into four categories depending on the shape and the number of the flaps and their position (Weiner \& Najt, 1991b);

2. The pseudocelli in Onychiurinae, and Tetrodontophorinae have a smooth pseudocellar lid, which is separated from the surrounding coarse secondary granulated integument by a distinct circular furrow of primary or low secondary granulation. The pseudocellar lid bears $6+6$ to $20+20$ ribs in two parallel rows delineated by a central superficial groove (Dallai, 1973); 
3. Rusek (1984) described a third type of pseudocelli found on the trochanters of members of the genus Onychiurus Gervais, 1841 and named them "trochanteral pseudocelli". They are smaller than type 2 pseudocelli and lack a circular furrow. These pseudocelli are also found on other part of the body: On the subcoxae in Allonychiurus Yoshii, 1995 (= Paronychiurus Bagnall, 1948; see Weiner, 1989b); on anal valves in Onychiurinae (Christian, 1989); on the first antennal segment in Tetrodontophora bielanensis (see Christian, 1989); and on various body segments of Hymenaphorura Bagnall, 1948 both ventrally and dorsally (Pomorski, 1990; Weiner \& Fjellberg, 1994). Weiner \& Fjellberg (1994) proposed to name these structures parapseudocelli.

Pseudocelli are completely absent on the ventral side and legs of Tullbergiinae (Rusek, 1984) and Tetrodontophorinae.

Several hypotheses were developed to explain the role of pseudocelli. Koncek (1924) advocated a haemorragic function. Others proposed both an excretion and a defense function against predators by extruding repellent fluids (Hale \& Smith, 1966; Usher \& Balogun, 1966). Rusek and Weyda (1981) considered the excretion function only.

In addition to pseudocelli, tegument structures are also found in other groups; particularly the pseudopores observed in Oncopoduridae (Szeptycki, 1977), Entomobryidae, Tomoceridae, and Isotomidae (Deharveng, 1978). According to morphology and position of pseudopores, one could wonder if these structures would be homologous to the pseudocelli. A detailed study using the electron microscopy would be necessary to establish or reject that hypothesis.

Chaetotaxy. Several authors have acknowledged the utility of chaetotaxy for phylogenetic inference (Deharveng \& Bedos, 1991; Luciáñez \& Simón, 1993). Chaetotaxy has been successfully used in lower level phylogenies (species or genera level, e.g., Deharveng \& Bedos, 1991; D'Haese, 2000; D'Haese \& Weiner, 1998; Luciáñez \& Simón, 1993). However, one might argue that it would be difficult to use it for higher-level phylogenies as homologies are more difficult to assess (but not impossible as it will be shown here and see D'Haese, 2002), and setae can bring a highly homoplastic signal.

Springtails possess chaetotaxic assemblages in which setae have defined positions, which are dispatched according to specific patterns (Nayrolles, 1988; Nayrolles, 1991; Nayrolles \& Betsch, 1993). The chaetotaxic nomenclature proposed here is based on adjustments to the works of Yosii $(1956$; 1971), Cassagnau (1974) and Grow \& Christiansen (1974).

Chaetotaxy of $s$ setae. Four main types of setae are possessed by springtails: Ordinary setae, sensilla (also named setae s), scales and trichobothria (Massoud \& Ellis, 1977). Neither scales and trichobothria, nor multilaterally ciliate setae are found in Poduromorpha. Sensilla of the body and of the antennae are distinguished here: The term "sensilla" is used for those of the antennae; and "setae s" refers to sensilla of the body. In comparison to ordinary setae, setae s are smooth, blunt and have a different refractiveness under the compound microscope. They are usually subcylindrical, but can be candle flame shaped, "francisque"-shaped, etc. (Massoud \& Ellis, 1977).

Within the Poduromorpha, setae s chaetotaxy is stable (with the exception of Onychiurinae and Tetrodontophorinae) compared to ordinary chaetotaxy, which is often plurichaetotic (Deharveng, 1979a). On the contrary, chaetotaxy of fourth antennal segment can present plurichaetoses or paurochaetoses of the sensilla independently in different groups.

The four families Hypogastruridae, Odontellidae, Neanuridae and Isotogastruridae possess a stable and scarce setae $\mathrm{s}$ chaetotaxy: $2+2$ setae $\mathrm{s}(1+1$ setae $\mathrm{s}$ in the $m$ row, and $1+1$ in the $p$ row), and $0+0$ or $1+1$ microsensilla on meso- and metathorax, $1+1$ setae $s$ (in $\mathrm{p}$ row) on tergum of abdominal segments I to V. Podura aquatica has the same setae s chaetotaxy, even if setae $s$ are indistinct from ordinary setae. Brachystomellidae are slightly different: some species have $2+2$ setae $s$ on abdominal segments. Head, prothorax, and sixth abdominal segment never bear setae s in Hypogastruridae, Odontellidae, and Neanuridae.

Setae s chaetotaxy of Onychiuridae is not well differentiated and difficult to interpret insofar that these setae are very difficult to distinguish from ordinary setae. More precisely, Onychiurinae have an abundant and not welldifferentiated chaetotaxy of setae s (Deharveng, 1979a). Some species, for example in the genera Psyllaphorura Bagnall, 1948, Oligaphorura Bagnall, 1949, and Tantulonychiurus Pomorski, 1996 possess setae s on the head. In the two latter, there is $2+2$ setae $s$ on the head (or $3+3$ in some Psyllaphorura, see Weiner \& Najt, 2000) and on abdominal segments I to III and $1+1$ on the sixth (Pomorski, 1998; Weiner, 1996). Tullbergiinae have a setae s chaetotaxy which is difficult to determine, but it seems stable compared to Onychiurinae setae s chaetotaxy and closer to Hypogastruridae one. Particularly, 1+1 setae s are clearly distinct on the fifth abdominal segment.

\section{Head}

The position of the head has been a taxonomic criterion used by some authors to establish phylogenetic relationships (e.g., Paclt, 1956; Salmon, 1964). Both authors considered Arthropleona prognathous and Symphypleona s.l. and Podura hypognathous. This was the major justification for placing Podura aquatica within the Metaxypleona, an ensemble including Actaletidae, Metaxypleona being sister group to the Symphypleona s.l. (Moen \& Ellis, 1984; Salmon, 1964). However, according to my own observations, Podura aquatica is prognathous when alive. The head bends downward with sudden death (when put in alcohol for example). It is important to note that the hypognathous position in Symphypleona is correlated with the important development of the clypeal area. This is not the case with Podura aquatica. The number of clypeal setae, or pre-labral setae, is reduced to two or four in Poduromorpha whereas there are more in Podura 
TABLE 1. Correspondences between existing systems of nomenclature for cephalic setae.

\begin{tabular}{cc}
\hline Cassagnau (1974) & Yosii (1956) \\
Najt \& Rubio (1978) & Da Gama (1964) \\
\hline $\mathrm{d} 1$ & $\mathrm{~A}$ \\
$\mathrm{~d} 2$ (unpaired) & $\mathrm{O}$ \\
$\mathrm{d} 3$ & $\mathrm{C}$ \\
$\mathrm{d} 4$ & $\mathrm{~F}$ \\
$\mathrm{~d} 5$ & $\mathrm{G}$ \\
$\mathrm{sd} 3$ & $\mathrm{~B}$ \\
$\mathrm{sd} 4$ & $\mathrm{E}$ \\
$\mathrm{sd} 5$ & $\mathrm{D}$ \\
Oc1 & Oc p \\
Oc2 & Oc m \\
Oc3 & Oc a \\
$\mathrm{c} 1$ & Di1 \\
$\mathrm{c} 2$ & De2 \\
$\mathrm{p} 1$ & Di2 ? \\
$\mathrm{p} 2$ & De1 ? \\
\hline
\end{tabular}

aquatica (on average ten to 20). This character places $P$. aquatica close to the genus Paraxenylla Murphy, 1965 which has a comparable clypeal chaetotaxy. The position of Paraxenylla in Poduromorpha has never been challenged.

The head also possess two different kinds of sense organs: eyes and PAO.

1. Springtails have eight simple eyes on each side of the head. These ocelli always have the same position with respect to each other. These have been annoted $\mathrm{A}$ to $\mathrm{H}$ (Guthrie, 1906). In many lineages, this number is reduced to complete absence, especially in euedaphic species (Thibaud, 1976; Thibaud \& Massoud, 1973).

2. The postantennal organs (PAO) are located on each side of the head in front of the ocular area, posterior to the base of the antennae. The precise function of this sense organ is unknown. It could have an olfactory function (Dallai, 1971), as well as sensitivity to temperature and humidity (Altner \& Thies, 1976). It is reduced to a setae-like structure, a "peg", in Symphypleona (Dallai, 1971) and absent in some Entomobryomorpha (Entomobryidae). In Poduromorpha, the PAO is composed of a variable number of vesicles and comprises a sensory cell in which the perikaryon is located in the central nervous system (Karuhize, 1971). The shape, number, structure of vesicles and the number of rows as well as the position of the vesicles in these rows can be highly variable in the different groups. These are fundamental criteria in Onychiuridae taxonomy (Pomorski \& Skarżyński, 1992; Weiner, 1996), and to a lesser extent in other groups like Pseudachorutinae (Massoud, 1967). The postantennal organ is absent in Neanurinae. Based on the connections to the nervous system, some authors considered the PAO homologous to the Tömösváry organ in Myriapoda (Denis, 1926; Willem, 1900). François (1969) proposed that the pseudoculi in Protura are homologous to the
Tömösváry organ, whereas Tuxen (1959) considered them vestiges of antennae. Recent studies tend to accept the homology of these organs among the three groups (Bitsch \& Bitsch, 1998; Edgecombe et al., 2000; Haupt, 1979).

Head chaetotaxy. Homologies of cephalic setae have been established with several morphological landmarks, mainly on the basis of:

1. Relative positions of the setae to each other;

2. Relative position of the setae to the muscular insertion marks on the cuticle (Najt \& Rubio, 1978);

3. Relative position of the setae to the transversal fissure separating the frontal area from the basis of the head and the fissures demarcating the ocular areas.

In Table 1, are proposed the correspondences between cephalic nomenclatures proposed by Cassagnau (1974) and Najt \& Rubio (1978) for the Hypogastruridae and Tullbergiinae and the nomenclature proposed by Yosii (1956) and da Gama (1964) for the Neanurinae.

These correspondences were partially given by Cassagnau (1980). However, he considered $\mathrm{A}=\mathrm{sdl}, \mathrm{O}=\mathrm{dl}$, $B=d 2$, and $E=s d 4$. The present proposal (Table 1) is probably more accurate insofar as in Cassagnau's system the unpaired setae replace the $\mathrm{d} 1$ setae. Then, it assumes sd row with 6 setae (one more posterior to sd1) in the genus Friesea Dalla Torre, 1895 (Fig. 2C), and B setae (supposed to be d2) would be distant from the axis of $\mathrm{d}$ row in Neanurinae (Fig. 2E). Primary homology criterion leads to rejection of that hypothesis. The replacement of two symmetric setae by one seta in the axis (paurochaetosis by axial substitution) presents an intermediary state in species with two asymmetrical setae (Deharveng, 1983), as in some species in the genus Anurida for example.

Jordana et al. (1997) proposed a nomenclature for cephalic setae in Onychiurinae. However, the interpretation of the $d$ row is erroneous in this work as $\mathrm{d} 5$ do exist and $\mathrm{d} 0$ is the unpaired expression of setae $\mathrm{d} l$, (already stated by Pomorski, 1996). Setae d5 is not homologous to the unpaired setae $d$ in Friesea (in this genus $d 2$ is unpaired). In the genus Triacanthella Schäffer, 1897 there is also an unpaired setae d. It is probably homologous with $\mathrm{d} 0$ setae in Onychiurinae. However, homologies are difficult to established in Triacanthella because of the plurichaetoses.

Part of the diversity of cephalic chaetotaxy in Poduromorpha is presented in Figs $1 \mathrm{~B}-\mathrm{F}$ and $2 \mathrm{~A}-\mathrm{E}$. Chaetotaxy of a first instar of Folsomia candida (Entomobryomorpha, Isotomidae) is provided in Fig. 1A. Row sd' in Onychiuridae is probably homologous to row oc. According to observations in Onychiurus first instar, sd'1 $=o c 1$ and sd' $2=$ oc2 (oc2 is always a big setae compared to the other oc setae) (personal observations and Pomorski, 1996). In Onychiurinae, there are several rows of setae (rows $\mathrm{cm}, \mathrm{cb}, \mathrm{cp}$ ) between rows $\mathrm{v}$ and $\mathrm{p}$ (Fig. 1D). These rows are not found in other Poduromorpha, which possess row c only (Fig. 1C). Along the same vein, Onychiurinae can have the unpaired setae a0, a' 0 and $a 0^{\prime}$ 

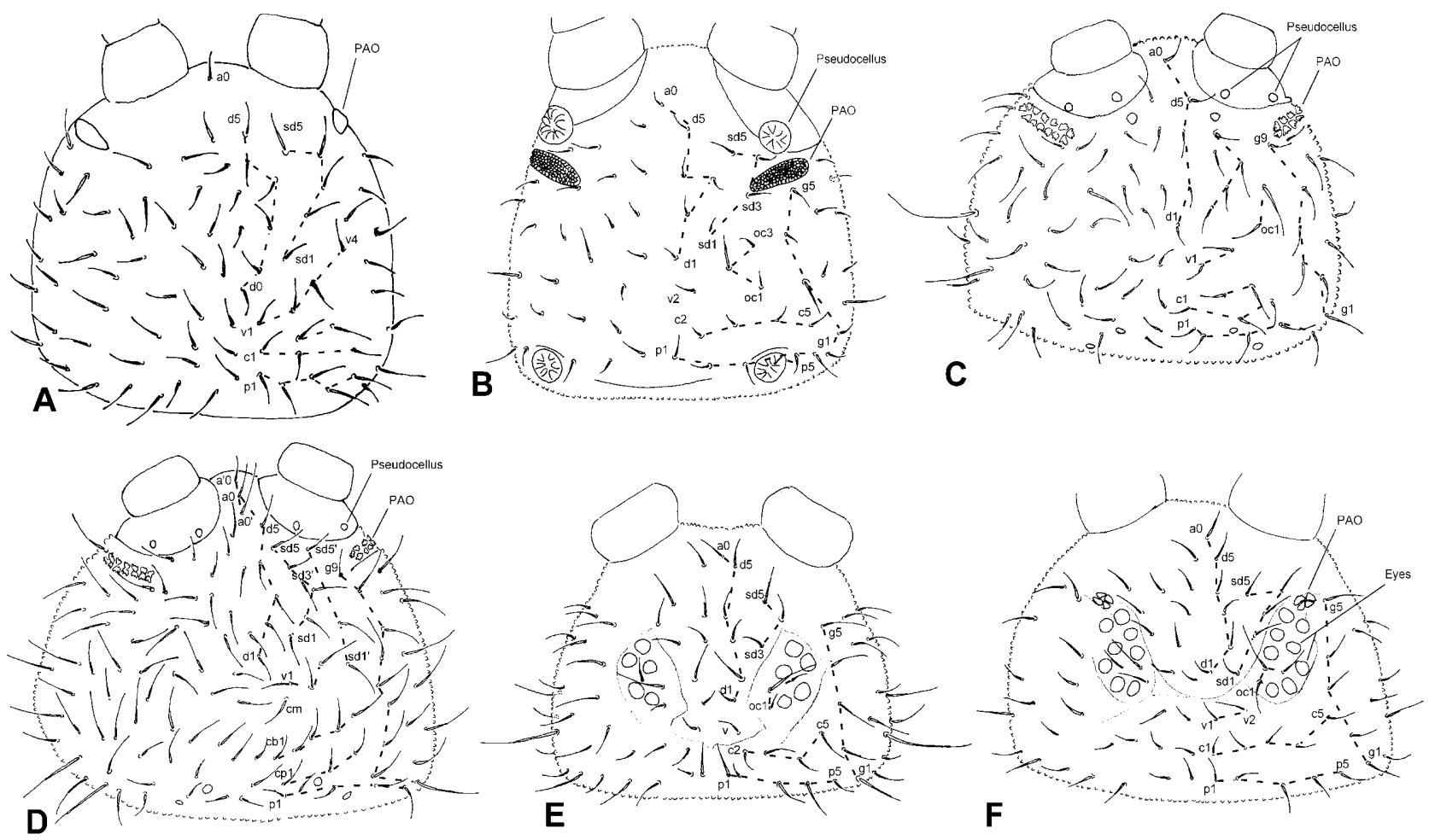

Fig. 1. Head chaetotaxy. A - Folsomia candida (Isotomidae), first instar; B - Scaphaphorura arenaria (Onychiuridae: Tullbergiinae); C - Onychiurus ambulans (Onychiuridae: Onychiurinae), first instar; D - Onychiurus ambulans, adult; E - Hypogastrura vernalis (Hypogastruridae); F - Xenylla grisea (Hypogastruridae). PAO - postantennal organ.

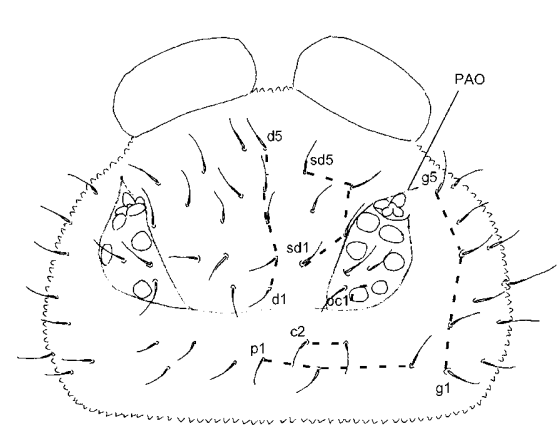

A

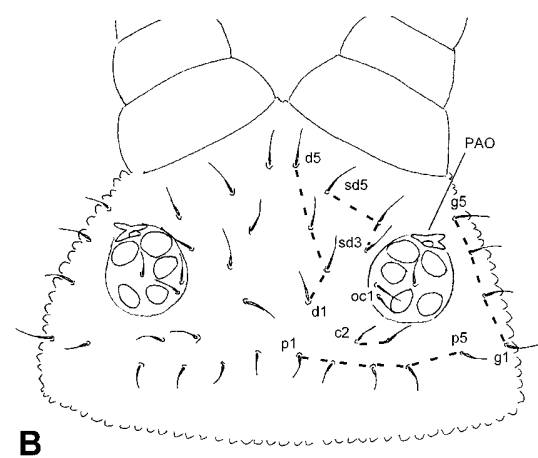

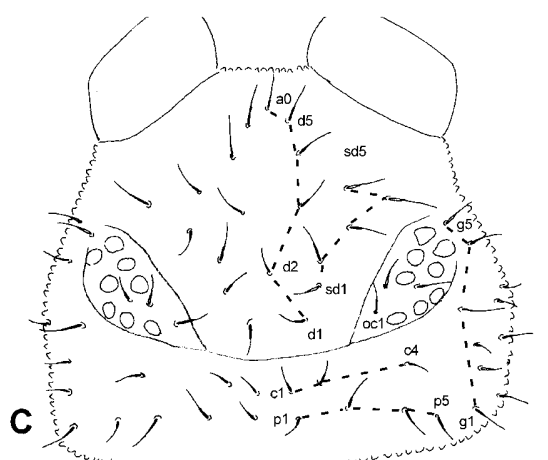

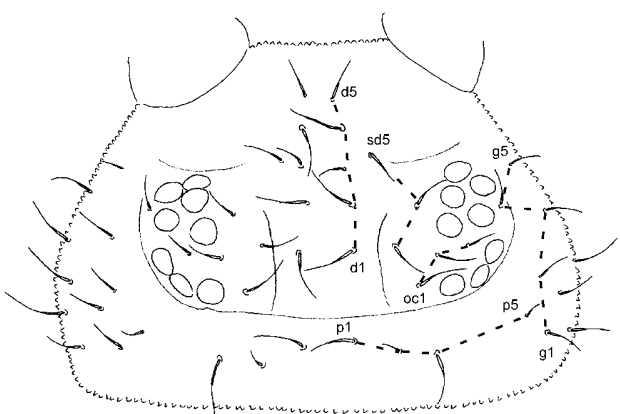

D

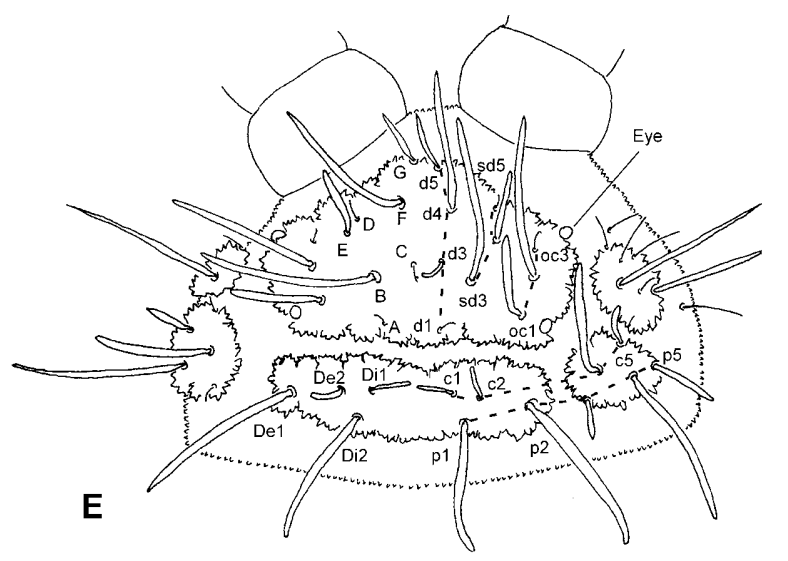

Fig. 2. Head chaetotaxy. A - Microgastrura sensiliata (Hypogastruridae); B - Superodontella gisini (Odontellidae); C - Friesea truncata (Neanuridae: Frieseinae); D - Pseudanurida sawayana (Neanuridae: Pseudachorutinae); E - Monobella grassei (Neanuridae: Neanurinae). 

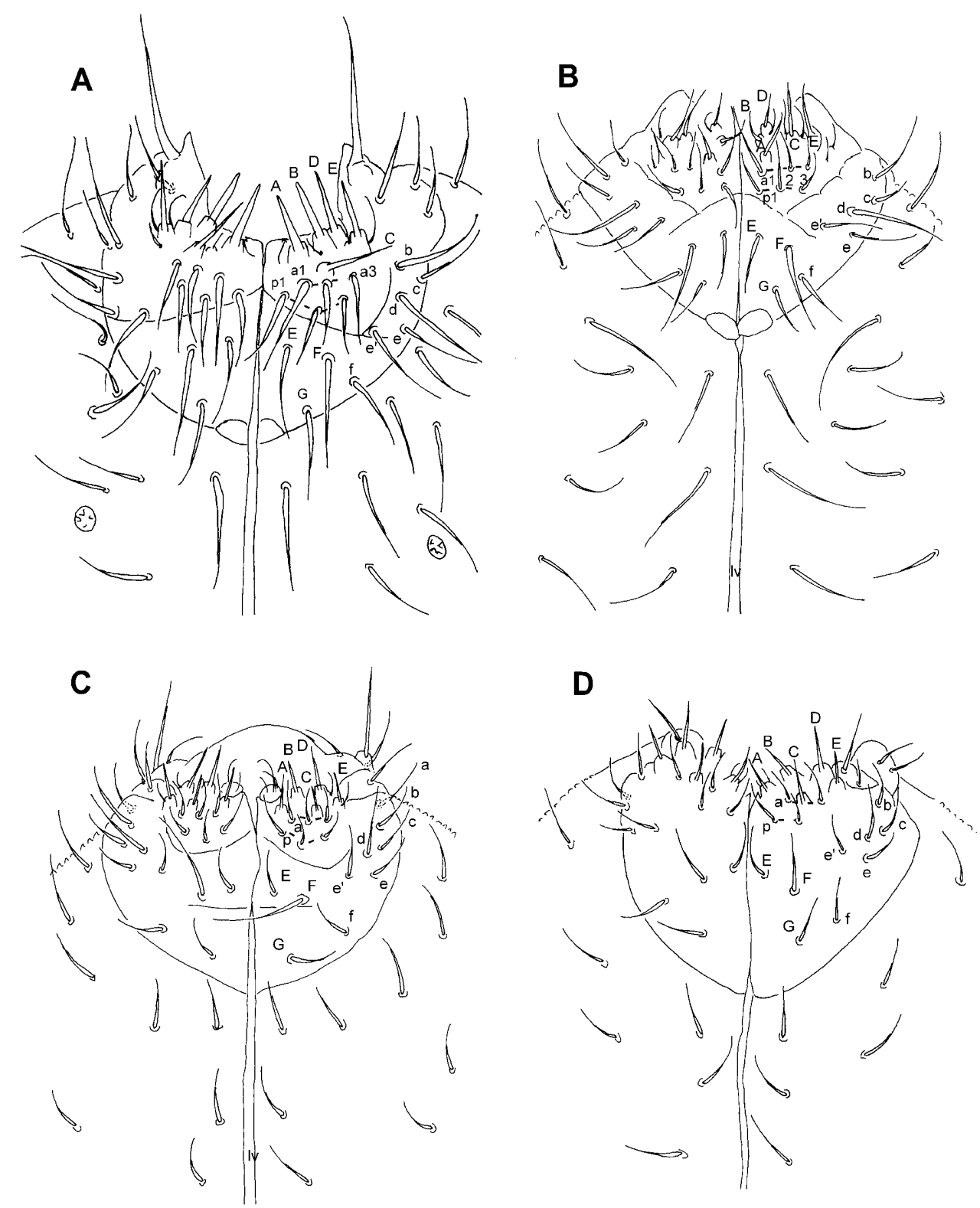

Fig. 3. Labium. A - Onychiurus ambulans (Onychiuridae: Onychiurinae); B - Tullbergia bisetosa (Onychiuridae: Tullbergiinae); $\mathrm{C}$ - Xenylla grisea (Hypogastruridae); D - Willemia denisi (Hypogastruridae). lv - linea ventralis. Chaetotaxy of the area posterior to labium Onychiurus is incomplete here: there are 4 rows of setae.

(Fig. 1D) whereas the other Poduromorpha have one unpaired setae a0 (Figs 1B, 1E-F, and 2A-E).

Setae $\mathrm{v}$ are absent in Neanuridae, Brachystomellidae and Microgastrura Stach, 1922 (Figs 2A-E). There are $1+1$ setae $\mathrm{v}$ in every species of the genera Xenylla Tullberg, 1869 (Fig. 1F), Willemia and Paraxenylla, 2+2 in the other Hypogastruridae (Fig. 1E) and Tullbergiinae (Fig. 1B) and $3+3$ or more setae in Onychiurinae.

In Hypogastruridae, setae c form a complete row of $5+5$ setae (Hypogastrura, Bourlet, 1839, Ceratophysella Börner, 1932, Paraxenylla), 4+4 setae (Xenylla, Willemia), $3+3$ (Friesea) 2+2 (Podura); in Odontellidae row c comprises from $1+1$ to $3+3$ setae.

Buccal cone. Collembola are entognathous, with a buccal cone on the anterior part of the head that encloses the mouthparts. This buccal cone is formed dorsally by the clypeus, which is extended by the labrum and ventrally by the labium, split into two parts by the linea ventralis. There are two main kinds of buccal cone: short, truncated (Figs 3A-D, 4A-B), and hemispherical when viewed from the side. This condition is found in most Poduromorpha: Hypogastruridae, Onychiuridae, Brachystomellidae, Frieseinae, and some Pseudachorutinae (i.e., Anurida); elongated, beak shaped (Figs 4C-D). The latter condition is found in Neanurinae (with simple mouthparts), some Pseudachorutinae (i.e., Pseudanurida Schött, 1901, Pseudachorutes Tullberg, 1871), and some Odontellidae.

Some species possess an intermediate state as that found in the genus Micranurida Börner. Elongation of the buccal cone could be correlated to the elongation of the 

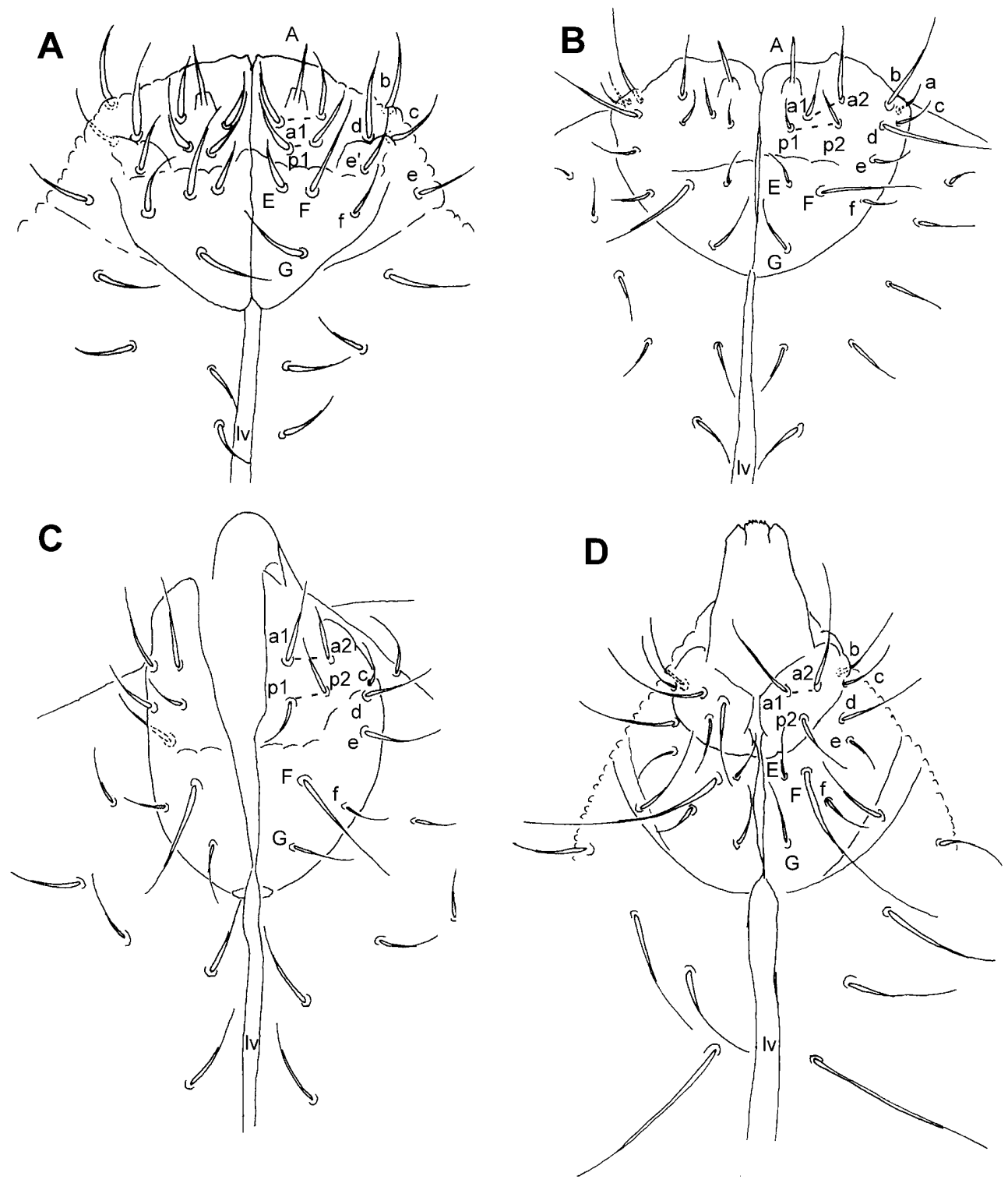

Fig. 4. Labium. A - Brachystomella parvula (Brachystomellidae); B - Friesea truncata (Neanuridae: Frieseinae); C - Pseudachorutes palmiensis (Neanuridae: Pseudachorutinae); D - Neanura muscorum (Neanuridae: Neanurinae). lv - linea ventralis.

maxillae, which could be linked to the feeding habits (Massoud, 1967).

Clypeal chaetotaxy is reduced to a few setae in most species. Podura and Paraxenylla have more setae and non-poduromorphan Collembola have many more. Prelabral chaetotaxy of Poduromorpha is formed by a row of four or two setae, or prelabral seate are absent (Najt \& Weiner, 2002). Generally, it is composed of four setae in Entomobryomorpha (Yosii, 1976), thought three in some Isotomidae and six in Symphypleona (Betsch, 1980).

Chaetotaxy of the labrum is formed by three rows of setae (usually 5-5-4 setae) in most of the Poduromorpha and two only in Neanurinae (3 in Caputanurinae: 5-5-2). Yosii (1976) counted four rows in some species (e.g., Anurida iriei Yosii, 1970, Brachystomella hawaiiensi Yosii, 1965, and Pseudachorutes kangchenjungae Yosii, 1966). However, it is more likely that his two first rows (with two and three setae respectively) are homologous of the first row (with five setae) in the three-rows system. The labrum in Entomobryomorpha and Symphypleona is rather uniform with a complete chaetotaxy of 5-5-4 setae with very few exceptions (Betsch, 1980; Chen et al., 1997; Yosii, 1967; Yosii, 1976).

Labium is formed by three distinct regions (Folsom, 1899; Massoud et al., 1975): labial palps (= setigerous lobe, Goto, 1972), mentum and submentum (the basilateral and basimedian field respectively). Labial palps possess two rows of setae inserted on papillae accompanied of guard setae (André, 1988; Fjellberg, 1999; Pomorski, 1996) three distally, and two posterior (A, C, D and F, E respectively in the nomenclature of Pomorski) (Table 2). The comprehensive nomenclature of Fjellberg (1999) is used here. Hypogastruridae and Onychiuridae possess a complete chaetotaxy with five papillae (A-E) (Figs 3A-D) as well as Entomobryomorpha and Symphypleona (Fjellberg, 1999). Brachystomellidae and Frieseinae have only 
TABLE 2. Correspondences between existing systems of nomenclature for setae on papillae and guard setae on labial palps.

\begin{tabular}{lccccccc}
\hline Massoud, 1967 & L & & & & & & \\
André, 1988 & lp1 & lp3 & lp6 & lp4 & lp5 & k & Г \\
Pomorski, 1996 & A & C & F & D & E & h & B \\
Fjellberg, 1999 & A & B & C & D & E & a1 & b1 \\
\hline
\end{tabular}

one papilla ( $\mathrm{L}=\mathrm{A}$ ) (Fig. 4A-B). In Pseudachorutinae, some species possess the papilla $A$ while others do not (Fig. 4C). They are completely lacking in Neanurinae (Fig. 4D). Posteriorly, there are two rows with three setae (including setae A, B, C, D), these are the proximal setae sensu Fjellberg (1999). I have reclassified the setae in two rows a and $p$ with three setae each in order to avoid confusion with the nomenclature of the papillae (Table 3 ). In the genus Friesea, there are four guard setae: a1-2 and p1-2 (Fig. 4B); In Anurida, Neanura Mac Gillivray, 1893, and Caputanurina, there are only three guard setae: a2 and p1-2 (Fig. 4D). In some Pseudachorutinae, Caputanurinae and Neanurinae, labial organites are found (Deharveng, 1983), between setae p1, a2 and p2.

Massoud (1967) proposed a nomenclature for mentum and submentum:

1. Mentum: setae e, d, c, b;

2. Submentum: setae E, F, G, f;

A seta e' has to be added to that nomenclature, above seta e. That seta e' is found in Onychiuridae and some Hypogastruridae (Figs. 4A-D). Homologies for mentum and submentum setae are proposed in Table 4 between nomenclatures of André (1988), Pomorski (1996) and Massoud (1967) and a proposed nomenclature based on Massoud's nomenclature.

The nomenclature of Pomorski (1996) for the setae posterior to labium is retained. Specifically, the number of setae in row $i$ are of phylogenetic value showing a variation in number from one row to five rows: Four to five rows in Onychiurinae, Isotogastrura Thibaud \& Najt, 1992 and Folsomia Willem, 1902; three in Tullbergiinae; three in Hypogastruridae; two in Neanurinae s.1.; one in the genus Microgastrura.

Mandibles. Springtails typically possess chewing-type mandibles. They are composed of a robust proximal component, which is pierced by a foramen allowing the insertion of mandibular muscles, and a distal part with a molar plate at the base and a toothed pars incisiva at the tip. Following the work of Stach (1949) and Gisin (1952), it was admitted that mandibles were lacking in Odontellidae (e.g., Massoud, 1967). However, they were observed in

TABLE 4. Correspondences between existing systems of nomenclature for mentum and submentum setae.

\begin{tabular}{|c|c|c|c|c|c|c|c|c|c|}
\hline \multirow[b]{2}{*}{ Massoud, 1967} & \multicolumn{4}{|c|}{ Submentum } & \multicolumn{5}{|c|}{ Mentum } \\
\hline & $\mathrm{E}$ & $\mathrm{F}$ & $\mathrm{G}$ & f & $\mathrm{e}$ & - & d & c & b \\
\hline André, 1988 & me1 & me2 & $\operatorname{sm} 1$ & $\sin 2$ & me4 & me3 & me5 & me6 & me7 \\
\hline Pomorski, 1996 & $\mathrm{p} 1$ & p3 & $\mathrm{p} 2$ & $\mathrm{p} 4$ & $\mathrm{a} 4$ & a5 & a3 & $\mathrm{a} 2$ & al \\
\hline $\begin{array}{l}\text { Proposed } \\
\text { nomenclature }\end{array}$ & $\mathrm{E}$ & $\mathrm{F}$ & $\mathrm{G}$ & f & $\mathrm{e}$ & e' & d & c & b \\
\hline
\end{tabular}

TABLE 3. Correspondences between existing systems of nomenclature for proximal setae on labial palps.

\begin{tabular}{lcccccc}
\hline Massoud, 1967 & A & B & C & D & - & - \\
André, 1988 & lb1 & Lb2 & lb3 & lb5 & lb4 & lb6 \\
Proposed nomenclature & p1 & a1 & a2 & p2 & a3 & p3 \\
\hline
\end{tabular}

the genus Stachia Folsom, 1932. Deharveng (1981b) in his study on Odontellidae clearly established that mandibles are always present in this family, even if they are reduced and do not have a molar plate (sometimes one asymmetrical mandibles only is present). All the prepared specimens of Odontellidae observed for this study had at least one mandible. In the same way, it was considered that Brachystomellidae did not have mandibles. But mandibles can be found in some genera (in Probrachystomellides Weiner \& Najt, 1991 and Winterella Massoud, 1967), they move under the stipes when prepared and are then difficult to see (Judith Najt, pers. com., Weiner \& Najt, 1991a). However, with the data to hand, it is difficult to assess if mandibles are absent in most Brachystomellidae or present and hidden by the stipes. The same goes for some Pseudachorutinae that seem to lack the mandibles as well (Najt \& Weiner, 2002).

The molar plate can be present (Entomobryomorpha, Symphypleona, Onychiuridae, Hypogastruridae) or absent (Odontellidae, Neanuridae). It is worth noting that the Hypogastruridae genus Microgastrura has an intermediate state, with a reduced molar plate. The pars incisiva bears either a few sub-equal teeth or is formed of a big basal tooth and smaller teeth at the tip. It is reduced to a sclerified spike in Odontellidae.

Maxillae. In the genus Hypogastrura, the maxillary palps (maxillary outer lobes) are simple and found on each side of the mouth with a sublobal plate including none to three sublobal setae. The number of sublobal setae is highly variable and so useful for the lower-level taxonomy of species identification (Fjellberg, 1984a). For example, in the genus Xenylla, 0, 1, 2 or 3 sublobal setae can be found depending on the species (Fjellberg, 1984b). Maxillary palps are found in Onychiuridae, Hypogastruridae and Poduridae, reduced in Odontellidae, highly reduced in Brachystomellidae and absent in Neanuridae.

In most Poduromorpha, the capitulum maxillaris is complete, and includes three teeth and six lamellae (Börner, 1908; Fjellberg, 1984b):

1. Lamella 1 (= median appendage, Börner, 1908) always the longest;

2. Lamella 6 (= median subsidiary appendage, Goto, 1972) in shape of small cushion, behind the basis of lamella 1 (in an axis teeth-lamella 1-lamella 6);

3. Lamella 2 and 3 ventral to lamella 6 ;

4. Lamellae 4 and 5 dorsal to lamella 6.

Many authors described the capitulum maxillaris in different species of Poduromorpha: Tetrodontophora Reuter, 1882 (Dallai, 1973), Hypogastruridae and Poduridae (Fjellberg, 1984b), Anurida (Folsom, 1900), Isotogastrura (Fjellberg, 1995), Brachystomellidae and Neanuridae (Massoud, 1967) and non-Poduromorpha: 
Isotomidae (Fjellberg, 1984a), Orchesella Templeton (Folsom, 1899), Folsomia (Goto, 1972), and Symphypleona (Betsch, 1980). A capitulum with three teeth and six lamellae is the most widespread form. It is found in most Hypogastruridae, Poduridae, Onychiurinae and Tetrodontophorinae and in Symphypleona and Entomobryomorpha. From that groundplan, many variations are observed: capitulum maxillaris with reduced number of lamellae (e.g., Frieseinae) or lamellae completely absent (Brachystomella Ågren, 1903), and capitulum more or less elongated, decrease or increase in the number of teeth etc.

In almost every Collembola, cardo, stipes and fulcrum are articulated in the following order: Stipes cardo fulcrum. In Odontellidae the stipes is directly articulated to the fulcrum (Deharveng, 1981b; Gisin, 1952). The cardo and the fulcrum can be either stocky (length/width ratio low) or thin (length/width ratio high). It is important to note that the length/width ratio of the cardo is small in Onychiuridae and Hypogastruridae, higher in Brachystomellidae and Frieseinae and still higher in Neanurinae. Actually, there is a cline from a stocky cardo (Hypogastruridae) to a thin cardo (Frieseinae) and even thinner one (Neanurinae). Cardo can be straight (Frieseinae, Brachystomellidae, and Neanurinae) or twisted (Hypogastruridae). The postero-internal extension of the fulcrum (p.p.i.) can be well developed as in Hypogastruridae and Onychiuridae, or reduced as in Neanuridae and Brachystomellidae (Deharveng, 1981b).

\section{Antennae}

The antennae are subdivided into four simple segments, each with its own intrinsic muscles. In some Symphypleona, the third and fourth antennal segments can be secondarily subsegmented (Betsch, 1980; Nayrolles, 1991), thus giving more flexibility to the antennae. Secondary segmentations are also observed in some Entomobryomorpha, namely Orchesellinae (Mari Mutt, 1988) and Tomoceridae. Antennae are inserted in the anterior part of the frontal area, and are in contact with the clypeal area. However, in Symphypleona they are inserted in the middle of the frontal area and make no contact with the clypeal area (Stebaeva, 1988). The region of the head near the antennae usually presents a distinct granulation (primary granules smaller) in Onychiuridae. Antennae are slightly shorter or sub-equal to the cephalic diagonal in Poduromorpha, significantly longer in Entomobryomorpha and Symphypleona, or significantly shorter than the cephalic diagonal in Neelipleona. It is worth noting that these ratios also reflect the proportions of the other appendices: legs and to a lesser extant, the furca. This is not true for Neelipleona, which have very short antennae despite the presence of well-developed legs and furcula. The proportions and shape of the four antennal segments are also potentially informative: the four segments can have the same width (resulting in subcylindrical-shaped antennae); segments can be decreasingly wide from base to tip, resulting in a more or less pronounced conical shape (a trend seen in Neanuridae and in Odontellidae). Antennae possess many sense organs, particularly at the tip: sense organ of the third antennal segment and above all the fourth antennal segment as a whole with many sensilla.

Generally, the first antennal segment contains seven setae: six arranged on one row and one more basally, near the external side. This conformation is observed almost uniformly in Poduromorpha (and Isotogastruridae) with few variations and with the exception of Onychiurinae, which possess one to three more setae. With ten setae, the first antennal segment chaetotaxy in the genus Triacanthella is very close to Onychiurinae. Primary chaetotaxy of Symphypleona is composed of seven setae as in Poduromorpha. There is only one seta on the first antennal segment in Neelipleona whereas Entomobryomorpha have a chaetotaxy with more than ten setae. The same kind of setae distribution is found on the second and third antennal segments. The second antennal segment bears from ten to 13 setae in most of Poduromorpha (including Triacanthella), with the exception of Onychiurinae, which have 15 to 17 setae. The third antennal segment bears from 21 to 22 setae in Onychiurinae and Triacanthella, and from 17 to 19 setae in the other Poduromorpha.

The sense organ of the third antennal segment is found in most Collembola. It is formed by five sensilla: two internal sensilla, two guard sensilla (one dorsal, one ventral), and one small ventral sensillum. These sensilla are accompanied by guard setae. Guard sensilla bend in the same direction in Hypogastruridae, and one against another in Tullbergiinae. It has to be said that tribes of Tullbergiinae have been defined according to the number of guard sensilla (Luciáñez \& Simón, 1993). However, according to their phylogenetic analyses, the three tribes were found to be paraphyletic. In Onychiurinae, Tetrodontophorinae and Isotogastruridae, the integumental papillae protect the sensilla of the third antennae sensory organ. In Tullbergiinae, the same structure is found but is not as developed as in Onychiurinae and Tetrodontophorinae.

A typical fourth antennal segment of Poduromorpha bears many sensilla, a subapical vesicle, a subapical organite and a dorso-external microsensillum. These sensillary structures can be developed or sometimes absent. The microsensillum can be located in the distal third portion of the fourth antennal segment, in the basal third portion or it can be absent. Another way to describe the position of the microsensillum is to consider its proximity to the subapical organite. Different nomenclatural systems for the sensilla of the fourth antennal segment have been proposed for different groups: Neanurinae (Deharveng, 1981a), Tullbergiinae (Rusek, 1976), the genus Ceratophysella (Yosii, 1962) and the genus Anurida (Babenko, 1997; Fjellberg, 1985a - both confused sensilla f with $\mathrm{c}, \mathrm{g}$ with $\mathrm{d}, \mathrm{c}$ with e and e with $\mathrm{f}$ ), the genus Willemia (Arbea \& Jordana, 1986; Fjellberg, 1994; Potapov, 1994) and for Xenylla jocquei André, 1988 (André, 1988). To date, no comprehensive system of nomenclature, which would indicate homologies, has been proposed. Table 5 summarizes the possible homologies for 


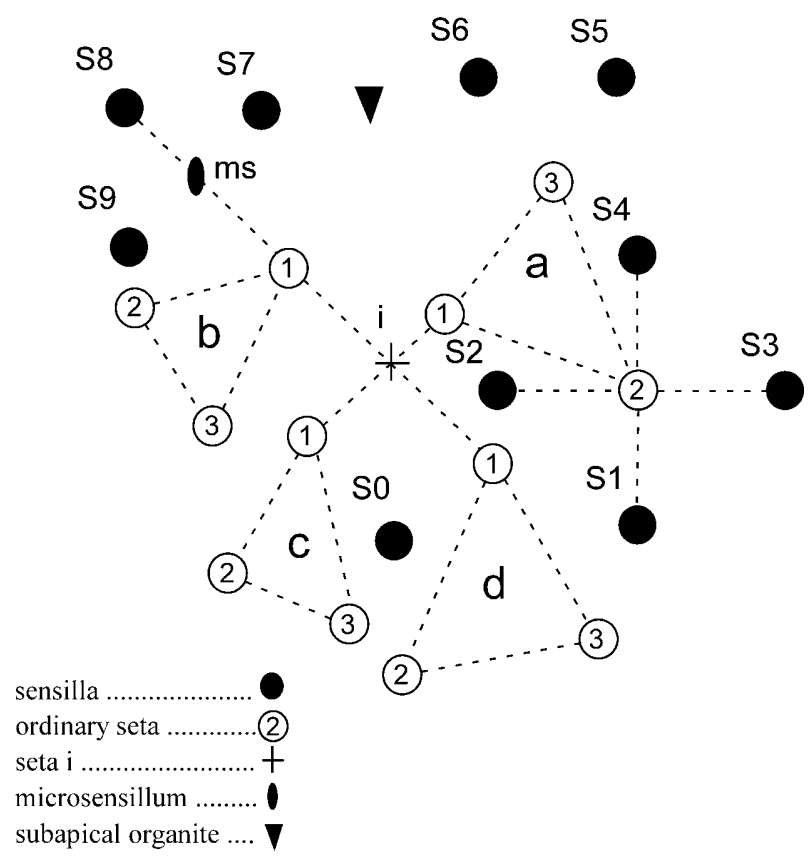

Fig. 5. Two-dimensional hypothetical scheme of a left fourth antennal segment of a Poduromorpha.

sensilla of the fourth antennal segment between the different groups and a proposition for a unified system.

Seta $x$ (Yosii, 1962) was named $i$ by Deharveng (1981a), m by Fjellberg (1985a) and ad3 by André (1988). Microsensillum f (Rusek, 1976) was named Se by Deharveng (1981a), s by Fjellberg (1985a), and wa4 by André (1988).

Homologies for sensillary structures of fourth antennal segment were established using the connections principle (Geoffroy Saint-Hilaire, 1818) with 4 main landmarks:

1. subapical organite;

2. dorso-external microsensillum ms;

3. seta $\mathrm{i}$ (acute seta, thinner and shorter than the other ordinary setae);

4. position of ordinary setae (in 4 triangles $a, b, c$, and $d$ made of 3 setae a1, a2, a3, b1, b2, b3, c1, c2, c3, d1, d2 and $\mathrm{d} 3$ (Deharveng, 1981a); named da $, \mathrm{dp} 3 \zeta, \mathrm{d} 4 \zeta$, ad4 $\zeta$, al $2 \zeta$, a $1 \zeta, \operatorname{ad} 2 \zeta,-, \operatorname{ad} 1 \zeta, \mathrm{d} 2 \zeta, \mathrm{d} 1 \zeta, \mathrm{dp} 1 \zeta$ respectively in the nomenclature of André (1988).

Some examples of position are given here: sensillumS7 $(=\mathrm{b}=\mathrm{e} 3=\mathrm{wa} 3)$ always located between the subapical organite (= wa1) and the microsensillum (= ms = wa4); dorso-external microsensillum located between S7 and S8; seta i located between the microsensillum or sensilla $\mathrm{S} 7$ and $\mathrm{S} 2$; a2 located at the intersection of segments [S1-S4] and [S2-S3]; S8, microsensillum, b1 and $i$ in alignment, $i$ at the intersection of segments [a1-c1] and [b1-d1] with a1-c1 < b1-d1 and i closer to a1 than c1; S2 located between a1 and d1. See Fig. 5 for a theoretical scheme of fourth antennal segment. Compared to this basic scheme, the microsensillum is located under the subapical organite in Tullbergiinae and is generally located at the base of fourth antennal segment in Onychiurinae. The unified nomenclature proposed here for the Poduromorpha with the exception of Onychiurinae and Tetrodontophorinae is based on the nomenclature proposed by Deharveng (1981a) for Neanurinae only. Sensilla $\mathrm{S} 0(=\mathrm{D})$ and $\mathrm{S} 9(=\mathrm{e} 1=\mathrm{se} 1=$ wa5 $)$ were added to sensilla S1 to S8 proposed by Deharveng. There are ten sensilla as a maximum, besides any plurichaetosis (Fig. 5):

1. Dorso-external sensilla: S7, S8, and S9;

2. Dorso-internal sensilla: S0, S1, S2, S3, S4, S5, and S6.

A very stable chaetotaxic scheme is observed in all the Neanurinae (Fig. 6A), with 8 sensilla S1, S2, S3, S4, S5, $\mathrm{S} 6, \mathrm{~S} 7$, and $\mathrm{S} 8$; the microsensillum is absent (Deharveng, 1981a). Caputanurinae show a very close structure with six sensilla S1, S2, S3, S4, S7, and S8 but without S5 and S6 (Fig. 6B). The same chaetotaxy is found in the genera Friesea (Fig. 6C), Pseudachorutes (Fig. 6D), Stachorutes Dallai, 1973, Pratanurida Rusek, 1973, Pseudachorutella Stach, 1949, Cassagnaudina Massoud, 1967, Gastranurida Bagnall, 1949, Micranurida, and Rusekella Deharveng, 1982 (in the latter two genera S2 is lacking). This six-sensilla scheme is observed in most of the species of the genus Anurida. However, some species of that genus possess a secondary plurichaetosis of the sensilla (one to four sensilla) that is located between sensilla S7

TABLE 5. Correspondences between existing systems of nomenclature for sensilla of fourth antennal segment and proposition for a unified system.

\begin{tabular}{lccccccc}
\hline $\begin{array}{l}\text { Deharveng, } \\
\text { 1981b }\end{array}$ & $\begin{array}{c}\text { Fjellberg, 1985a; } \\
\text { Babenko, 1997 }\end{array}$ & Yosii, 1962 & André, 1988 & $\begin{array}{c}\text { Arbea \& Jordana, Potapov,1994 } \\
1986\end{array}$ & $\begin{array}{c}\text { Rusek, 1976 } \\
\text { Unified } \\
\text { system }\end{array}$ \\
\hline Neanurinae & Anurida & Ceratophysella & Xenylla jocquei & Willemia & Willemia & Tullbergiinae & Poduromorpha \\
\hline- & - & D & - & - & - & - & S0 \\
S1 & F & E & - & sil & i1 & e & S1 \\
S2 & E & C & - & sd & d & - & S2 \\
S3 & D & G & wp2 & - & - & - & S3 \\
S4 & C & F & wp1 & si2 & i2 & c & S4 \\
S5 & - & - & - & - & - & - & S5 \\
S6 & - & - & - & - & - & - & S6 \\
S7 & B & B & wp3 & se3 & e3 & b & S7 \\
S8 & A & A & wa2 & se2 & e2 & a & S8 \\
- & - & - & wa5 & se1 & e1 & d & S9 \\
\hline
\end{tabular}



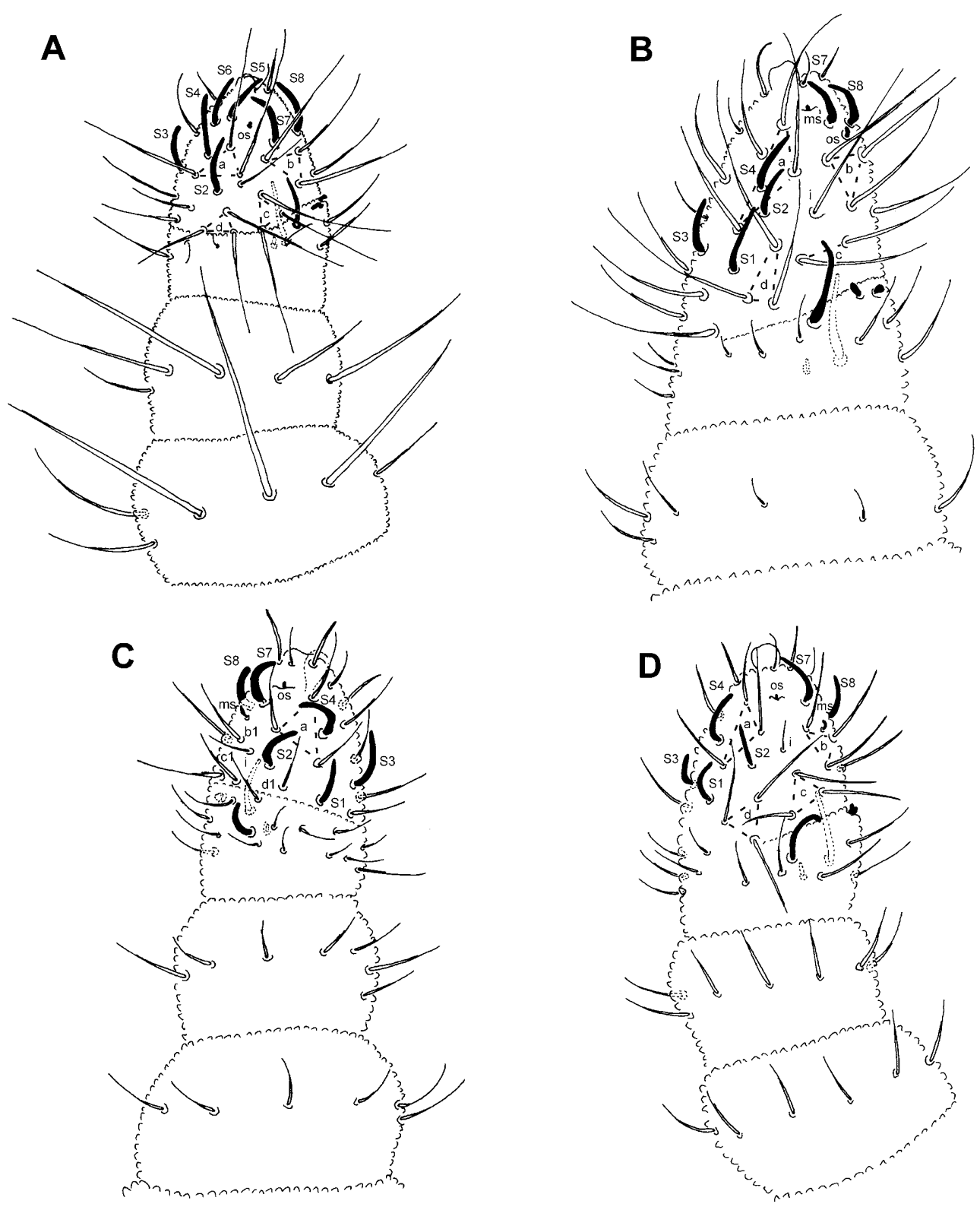

Fig. 6. Antenna. A - Neanura muscorum (Neanuridae: Neanurinae); B - Caputanurina turbator (Neanuridae: Caputanurinae); C Friesea truncata (Neanuridae: Frieseinae); D - Pseudachorutes parvulus (Neanuridae: Pseudachorutinae).

and S8 and sensilla S2 and S4 (for example in A. kolymensis Tshelnokov, 1988, A. parapapillosa Tshelnokov, 1988, A. caprariensis Dallai, 1969, A. thalassophila (Bagnall, 1939)).

Morulinae possess a chaetotaxy of sensilla which are not or only slightly distinct from ordinary setae (Deharveng, 1981a).

Important variations are observed in Odontellidae with plurichaetoses, mostly on the dorso-external side, or reductions. Xenyllodes Axelson, 1903 (Fig. 7A) and Superodontella Stach, 1949 possess sensilla S7, S8, and $\mathrm{S} 9$, the latter being relatively basal. Four other sensilla are found: S1, S2, S3, and S4 with slightly different positions in comparison to the other groups: S1 is slightly higher and more external, $\mathrm{S} 3$ has a more internal position and $\mathrm{S} 4$ is located a more interno-basally on the segment [a2-S3] and S2 positioned higher up under the subapical organit.
Compared to other families, it appears that sensilla S1, $\mathrm{S} 2$, and S4 rotated around the ordinary seta a2 clock-wise in a left-antennae, and S3 was pushed internally by S4 coming. Migration of these sensilla is perhaps correlated with the shortening of the basis of the fourth antennal segment (which causes the conical shape of the antennae). Another hypothesis would be that S3 (S4 in the previous hypothesis) does not really move and $\mathrm{S} 4$ (S3 in the previous hypothesis) migrates further, on the internal side. Both hypotheses require a rotation around ordinary seta a2.

Brachystomella parvula Schäffer, 1896 possess six sensilla S1, S3, S4, S7, S8, and S9; S2 seems to be absent.

The genera Ceratophysella (Fig. 7B) and Schaefferia Absolon, 1900 (Hypogastruridae) have sensilla S0, S1, S2, S3, S4, S7, and S8. Some species show variations, namely reductions (particularly the absence of S0) and 

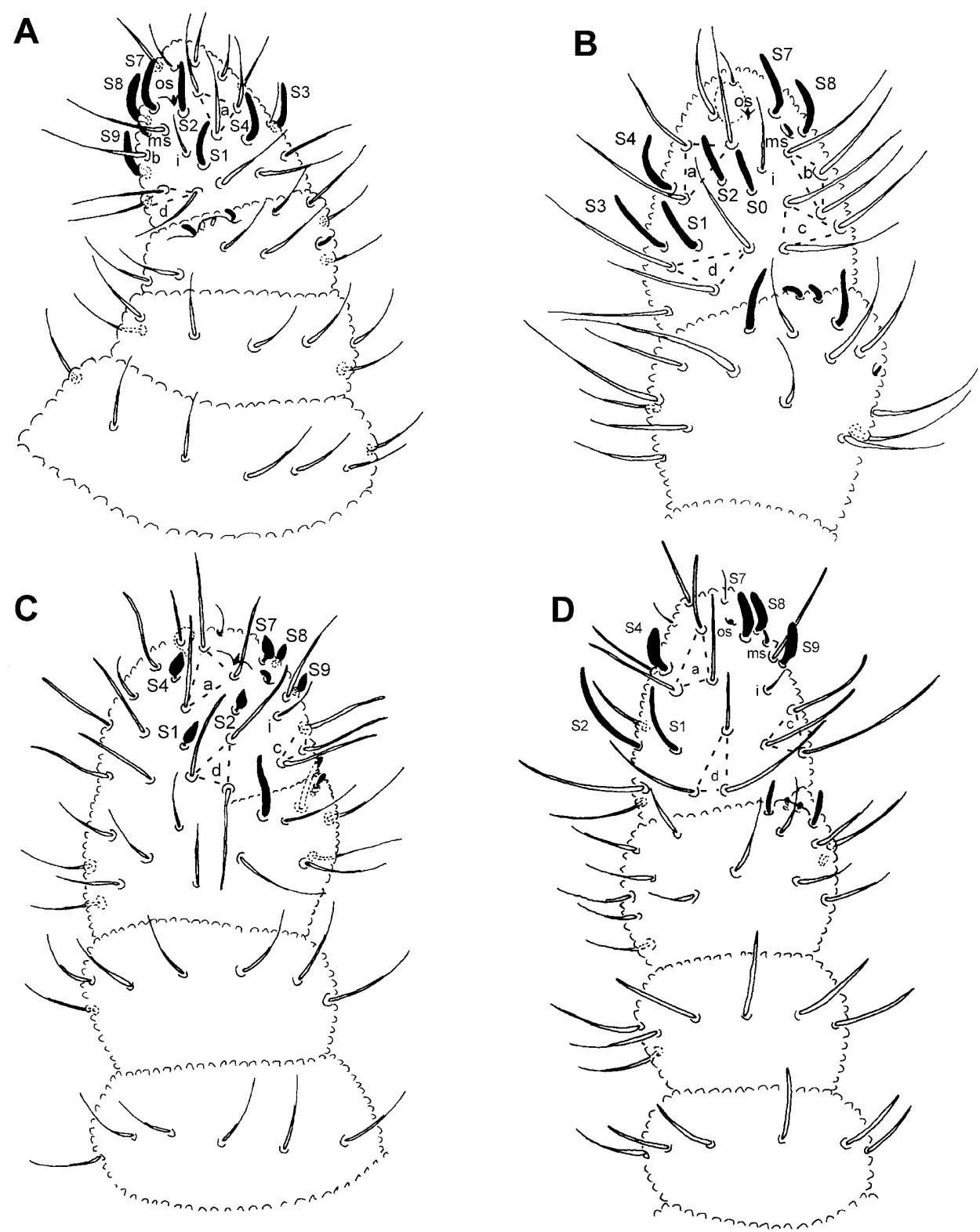

Fig. 7. Antenna. A - Xenyllodes armatus (Odontellidae); B - Ceratophysella gibbosa (Hypogastruridae); C - Willemia denisi (Hypogastruridae); D - Xenylla grisea (Hypogastruridae).

plurichaetoses of the dorso-internal side of antennae. Sensilla S1, S2, S3, S4, S7, S8, and S9 are present in Hypogastrura vernalis (Carl, 1901). The other species of the genus Hypogastrura have the same scheme or slight variations from this scheme, with reductions in the number of sensilla or secondary plurichaetoses. The genera Mucrella Fjellberg, 1985, Pseudacherontides Djanashvili, 1971, and Acherontiella Absolon, 1913 possess the same scheme (presence of sensilla S7, S8, and S9) with a reduction of dorso-internal setae. The genus Willemia (Fig. 7C) possesses sensilla S1, S2, S4, S7, S8, and S9, with secondary losses in some species (D'Haese, 1998, 2000; D'Haese \& Weiner, 1998). In the genus Xenylla (Fig. 7D) sensilla S4, S7, S8, and S9 are very thick, and sensilla S1 and S3 are very thin. The latter two are absent in some species, or more difficult to distinguish from ordinary setae. The same chaetotaxic scheme is found in the genus Paraxenylla, with sensilla S1 and S3 absent or indistinct from ordinary setae. In Microgastrura sensiliata Jordana, 1981 (Fig. 8A), sensilla S1, S2, S3, S4, S7, and S8 are present. Sensillum S3 has a more internal position in comparison to the other Hypogastruridae and S4 is located lower down on the axis [a2-S3]. In the other species of the genus, three dorso-external sensilla are found, including S9; its absence in $M$. sensiliata is probably a secondary loss.

Sensilla chaetotaxy of the fourth antennal segment of Tullbergiinae (Fig. 8B) is difficult to compare with sensilla chaetotaxy of Hypogastruridae, Odontellidae, Brachystomellidae, and Neanuridae. Five well-differentiated sensilla are found in Tullbergiinae: two dorso-externals and three dorso-internals. These could be homologous with sensilla S8 and S9 on one side and sensilla S1, S2, and $\mathrm{S} 4$ on the other side. It is worth noting that the micro- 
A
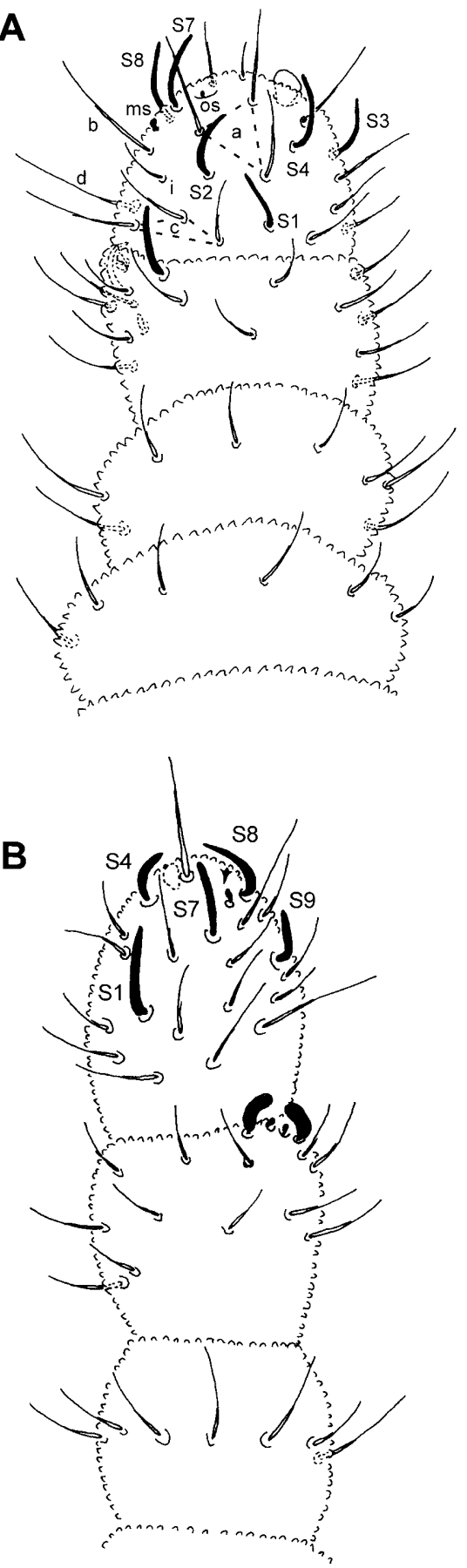

Fig. 8. Antenna. A - Microgastrura sensiliata (Hypogastruridae); B - Mesaphorura macrocheta (Onychiuridae: Tullbergiinae).

sensillum is located under the subapical organite, which has migrated to the external side of the antennae (the microsensillum is located between S7 and S8 in Hypogastruridae, Odontellidae, Brachystomellidae, and Neanuridae). It was not possible to identify seta $i$, as it is either absent or indistinct from the other ordinary setae. In Onychiurinae and Tetrodontophorinae the sensilla are indistinguishable when viewed under a compound microscope. In some species, the sensilla are visible (as in Psyllapho- rura Weiner \& Najt, 2000), however it was not possible to establish homologies.

Podura aquatica possesses a fourth antennal segment chaetotaxy very similar to Hypogastruridae, but the sensilla are not distinct from the ordinary setae.

Frequently, secondary losses or plurichaetoses of sensilla are observed independently in different groups.

\section{Thorax}

The prothorax is well developed in Poduromorpha and bears setae. It is well differentiated except in Caputanurina where it merges with the head (this is a diagnostic character of the genus); this merger is less complete in the other Caputanurinae. In Isotogastruridae, the prothorax is well developed but does not bear setae. The number of rows of setae and number of setae within these rows vary according to the different groups: 1 row of setae in Tullbergiinae, Hypogastruridae, Odontellidae, Brachystomellidae, and Neanuridae, 2 rows in Onychiurinae, more than 2 rows in Tetrodontophora bielanensis.

An organ present on the prothorax of Collembola's embryos may help hatching (Jura, 1967; Philiptschenko, 1912; Tamarelle, 1971, 1981; Thiegs, 1942; Wheeler, 1893). The organ has been found in the embryos of all Collembola studied thus far (Jura \& Krzysztofowicz, 1978). This organ can persist in the first instar. According to Deharveng (1983), this dorsal organite of the prothorax would be characteristic of the first instar of Neanurinae, but was observed in Caputanurinae (Caputanurina turbator Najt \& Weiner, 1992) and Brachystomellidae (Najt \& Weiner, 1992). According to my own observations, this structure is present in the first instar of Onychiurus ambulans, Mesaphorura macrocheta, Xenylla grisea, Neanura muscorum, and Folsomia candida (Entomobryomorpha, Isotomidae). Actually, this organite is widely present in Entomobryomorpha (Judith Najt, pers. com.). It is probably present in Collembola as a whole. The prothorax is highly reduced and does not bear setae in Entomobryomorpha, Symphypleona, and Neelipleona. In the first instar of Folsomia candida, the second thoracic segment bears one more row of setae than the third thoracic segment. More generally, the mesothorax bears additional rows of setae on the anterior part compared to the metathorax in the genera Tetracanthella, Isotomiella Bagnall, 1939, and probably in every Entomobryomorpha. The mesothorax and metathorax have an almost identical chaetotaxy in Poduromorpha. Additional rows of setae on the mesothorax may have originated ontogenetically from the prothorax. Some authors believe that the prothorax tergum is fused with the mesothorax (e.g., Denis, 1949).

The number of rows of setae on the meso-, and metathorax is variable among the different families. In Poduromorpha, two to five rows are observed, and more than five in Entomobryomorpha. Microsensilla on the metathorax are present in Onychiurinae (with few exceptions like Micraphorura pieninensis Weiner, 1988), Tetrodontophorinae, Tullbergiinae, and Odontellidae. Microsensilla are absent in Hypogastruridae, Brachystomellidae, and Neanuridae. Thoracic sternites can bear setae. However, that character is probably not very informative for 


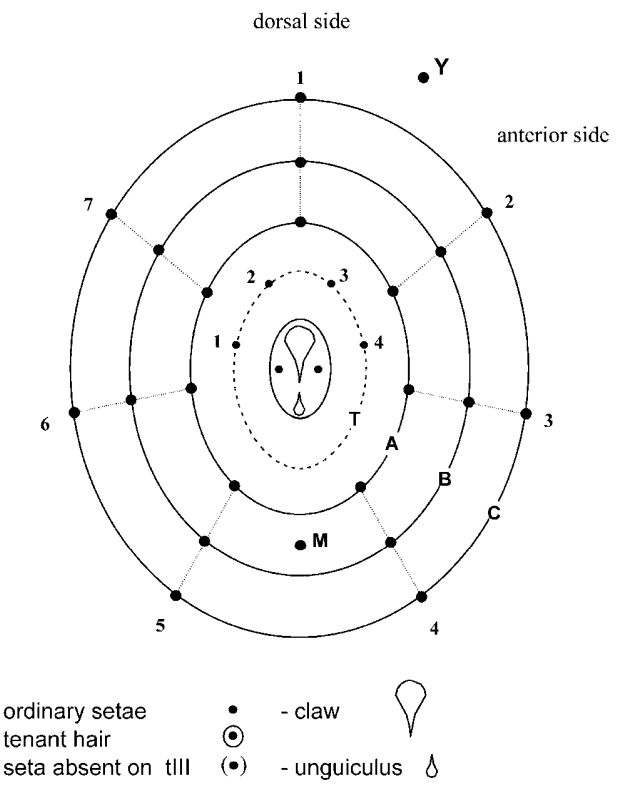

Fig. 9. Complete scheme of tibiotarsal chaetotaxy in Poduromorpha, right leg (after Deharveng, 1983).

Poduromorpha as a whole since those setae can be present or absent in the same genus.

\section{Legs}

Yosii (1962), Lawrence (1977), Deharveng (1983), and Nayrolles (1988) studied the chaetotaxy of tibiotarsi. In the present work, I will use the nomenclature proposed by Deharveng, which was based on the work of Lawrence (1977) (see Fig. 9 for a theoretical scheme of tibiotarsal chaetotaxy). This nomenclature has already been used to describe the tibiotarsi in Tullbergiinae (Fjellberg, 1991a), and in the genus Willemia (Fjellberg, 1991b).

Onychiurinae and Tetrodontophorinae have a complete tibiotarsal chaetotaxy, with the presence of the rows $\mathrm{A}, \mathrm{B}$, $\mathrm{C}$, and $\mathrm{T}$ as well as seta $\mathrm{Y}$, which is absent in the other groups (Figs 10 \& 11). This chaetotaxic scheme can be concealed by a secondary plurichaetosis (Tetrodontophora). Comparatively, other Poduromorpha have a less abundant chaetotaxy with row $\mathrm{C}$ and seta $\mathrm{Y}$ lacking. Hypogastruridae, Neanuridae, and Poduridae (Podura aquatica) are typical of this model, with generally 19 setae on tibiotarsi I and II, and 18 setae on tibiotarsi III split up into rows T, A, and B. Seta B7 is lacking on tibiotarsi III, except in Podura aquatica which possesses 19 setae on every tibiotarsi. Secondary losses are frequently observed in different groups, for example setae T2, and T3 are lacking in Willemia denisi, species of that genus have 17, 17, 16 setae at least (see Fig. 11). Rows A, and $\mathrm{B}$ can be relatively complete in Tullbergiinae (Fig. 10) and row $\mathrm{T}$ is always absent. Unguiculus (empodial appendage) is generally present in Onychiuridae, Odontellidae, and Hypogastruridae, but is often absent, particularly in the genera Podura, Xenylla, and Paraxenylla (Figs 11B, 11F \& 11G). It is always absent in Neanuridae, and Brachystomellidae (Massoud, 1967), see Fig. 12. Generally, in Neanuridae and Brachystomellidae, rows $T, A$, and $B$ are relatively complete and seta $M$ is present, with the exception of Frieseinae in which $M$ is always absent (Fig. 12) but in Friesea species of the south hemisphere (Deharveng \& Bedos, 1991; Greenslade \& Deharveng, 1997).

Leg chaetotaxy is fixed (no addition of setae during the development) from the first instar onward in Tullbergiinae, Odontellidae, Hypogastruridae, Brachystomellidae, and Neanuridae. During postembryonic development, setae are added on the legs in Onychiurinae (observations based on cultures of many species: Onychiurus, Kalaphorura Absolon, 1901, Protaphorura Absolon, 1901 etc.). Setae are also added during the development in nonpoduromorphan Collembola: in Symphypleona (Nayrolles, 1988), and more generally in Entomobryomorpha as a whole (cf. Fig. 13 for Isotomidae - personal observations).

Tibiotarsi have a decreasing antero-posterior gradient of the number of setae in Neanuridae, Hypogastruridae, and Onychiuridae (except for Protaphorura): seta B7 is absent on the third pair of tibiotarsi. It is the opposite in Isotomidae and Symphypleona. The tibiotarsi and femora also present a decreasing antero-posterior gradient of the number of setae in almost all Poduromorpha. The same applies for trochanters, with the exception of Onychiurinae with a postero-anterior gradient. In every Poduromorpha, the first and second subcoxae have a decreasing postero-anterior gradient of the number of setae. Coxae have a number of setae: leg I $<\operatorname{leg}$ II $=$ leg III in every Poduromorpha except in Onychiuridae and Podura aquatica in which leg I < leg II $<$ leg III.

In Poduromorpha and Isotomidae, the number of setae per row is seven (Deharveng, 1983). Eight setae per row are observed in Symphypleona (Nayrolles, 1998), and six in Neelipleona. The number of rows is fixed according to the different groups: four (rows T, A, B, and C) or less in Poduromorpha and Isotomidae (Deharveng, 1983), and five (rows I to V) in Symphypleona in first instar (Nayrolles, 1998).

The pretarsus terminates by a claw with three lamellae (these can also bear teeth) and an empodial tubercle, which bears the unguiculus. The unguiculus is formed by four lamellae in Symphypleona and Entomobryidae (Christiansen, 1965), three in Isotomidae and Tomoceridae and only one in Hypogastruridae.

The relative proportions of the different parts of the body are variable between the different groups of Collembola: Poduromorpha are relatively stocky, whereas Entomobryomorpha and Symphypleona possess elongate or very elongate appendages relatively to the body. This could be related to the habitat: generally edaphic in the former, more epigeic in the latter two. The legs are short compared to the length of the body in Poduromorpha, whereas they are long in Entomobryomorpha, Neelipleona, and Symphypleona. The ratio of tibiotarsus to claw reflects this: the ratio is near one in Poduromorpha, much higher in the others.

\section{Abdomen}

Entomobryomorpha and Poduromorpha possess an elongate and well-segmented body. On the contrary, the 

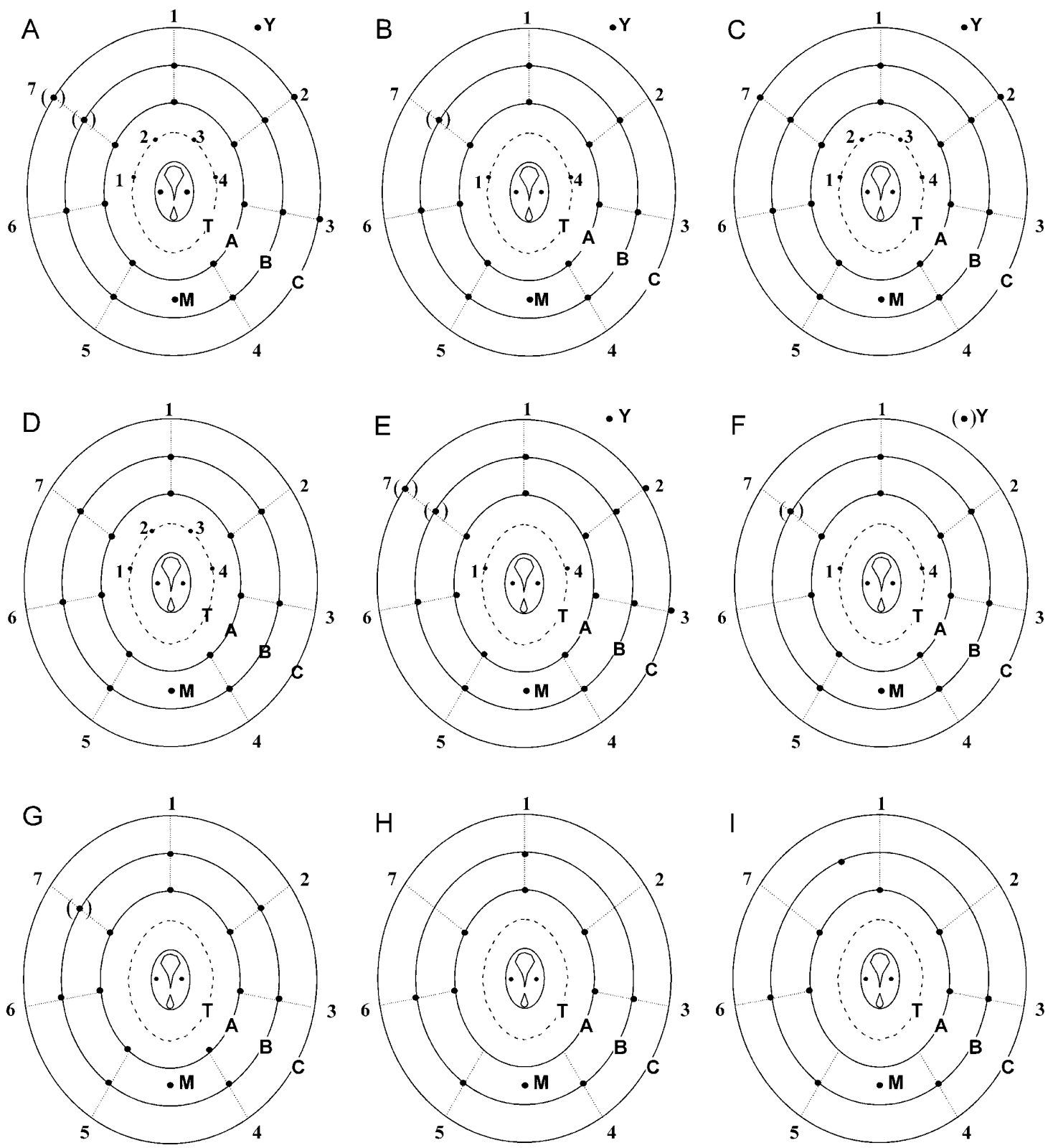

Fig. 10. Tibiotarsal chaetotaxy. A - Kalaphorura paradoxa (Onychiuridae: Onychiurinae); B - Micraphorura absoloni (Onychiuridae: Onychiurinae); C - Protaphorura armata (Onychiuridae: Onychiurinae), first and second tibiotarsi; D - Protaphorura armata (Onychiuridae: Onychiurinae) first instar; E - Onychiurus ambulans (Onychiuridae: Onychiurinae); $\mathrm{F}$ - Onychiurus ambulans first instar; G - Tullbergia bisetosa (Onychiuridae: Tullbergiinae); H - Mesaphorura macrocheta (Onychiuridae: Tullbergiinae); I - Scaphaphorura arenaria (Onychiuridae: Tullbergiinae). Notice the presence of row $\mathrm{C}$ and seta Y in Onychiurinae and the absence of seta $\mathrm{Y}$, row $\mathrm{C}$, and row $\mathrm{T}$ in Tullbergiinae.

Symphypleona and Neelipleona are globular. The Symphypleona have a characteristic globular shape formed by the enlargement and fusion of the posterior thoracic and anterior abdominal segments forming the large abdomen, and the last abdominal segments are distinct, forming the small abdomen (e.g., Betsch, 1980). On the other hand, the globular body of Neelipleona is one whole structure and is mainly the result of the enlargement of the thoracic segments (Massoud, 1971a).

Poduromorpha have well-developed and sub-equal abdominal segments. Entomobryomorpha present fusions of some of the segments: fusion of fourth and fifth abdominal segments or fusion of the fourth, fifth, and sixth abdominal segments. The fourth abdominal segment is normally developed in Poduromorpha, Isotomidae and Tomoceridae, and longer in other Entomobryomorpha, Symphypleona, and Neelipleona (Massoud, 1971a).

Dorsal chaetotaxy is described here with the classic system with three rows of setae: anterior (a), middle (m), and posterior (p) proposed by Yosii (1956), and developed for Hypogastruridae by Cassagnau (1974) and Grow \& Christiansen (1974), and applied to Poduromorpha as a whole. Fjellberg (1985b) established the correspondences between the classic rows a, m, and p system and the system of Di, De, Dl, and L that Cassagnau (1980) and Deharveng $(1979 b ; 1983)$ developed for Neanurinae. 

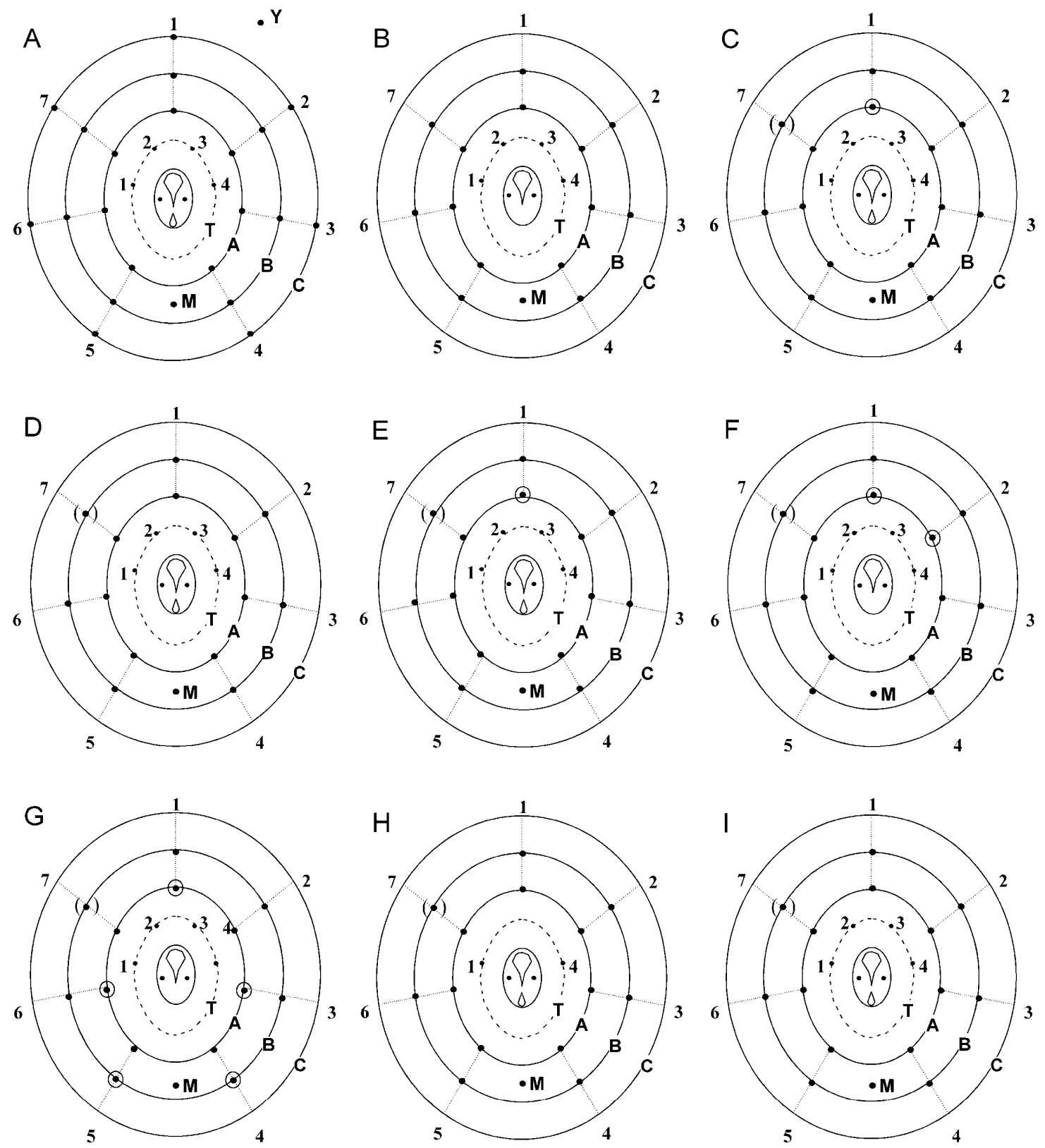

Fig. 11. Tibotarsal chaetotaxy. A - Lophognathella choreutes (Onychiuridae: Tetrodontophorinae); B - Podura aquatica (Poduridae); C - Triacanthella perfecta (Hypogastruridae); D - Ceratophysella gibbosa (Hypogastruridae); E - Hypogastrura vernalis (Hypogastruridae); F - Xenylla tullbergi (Hypogastruridae); $\mathrm{G}$ - Paraxenylla affiniformis (Hypogastruridae); $\mathrm{H}$ - Willemia denisi (Hypogastruridae); I - Microgastrura sensiliata (Hypogastruridae). Notice the presence of row C, and seta Y in Tetrodontophorinae, their absence in Hypogastruridae and Poduridae.

On the ventral side, the unpaired setae chaetotaxy is of interest. They are present in Onychiuridae but seem to be absent in Hypogastruridae, Odontellidae, Brachystomellidae, and Neanuridae. The number of ventral setae rows is more important in every segment in Onychiurinae, and Tetrodontophorinae compared to the other Poduromorpha. One or two unpaired setae are found on the sixth abdominal segment in Triacanthella, every Tullbergiinae, and most of Onychiurinae. Ventrally, between the anus and the anal spines, there are a maximum of three unpaired setae (the most distal seta can be transformed to an unpaired anal spine). There are no unpaired setae on sixth abdominal segment in Neanurinae. On the other hand, there are three unpaired setae between the anal spines and anus and two unpaired setae on the tergum in Tullbergiinae. Anal spines can be present or absent. However, this character is highly homoplastic in Poduromorpha since both character states can be found in the same genus (e.g., in the genus Willemia, D'Haese, 2000).

Anal valves. Within Poduromorpha, two types of anal valves can be found:

1. The three valves are sub-equal, and non-overlapping; the supra-anal valve has a convex edge (Fig. 14A). These kinds of anal valves are found in Onychiurinae, 

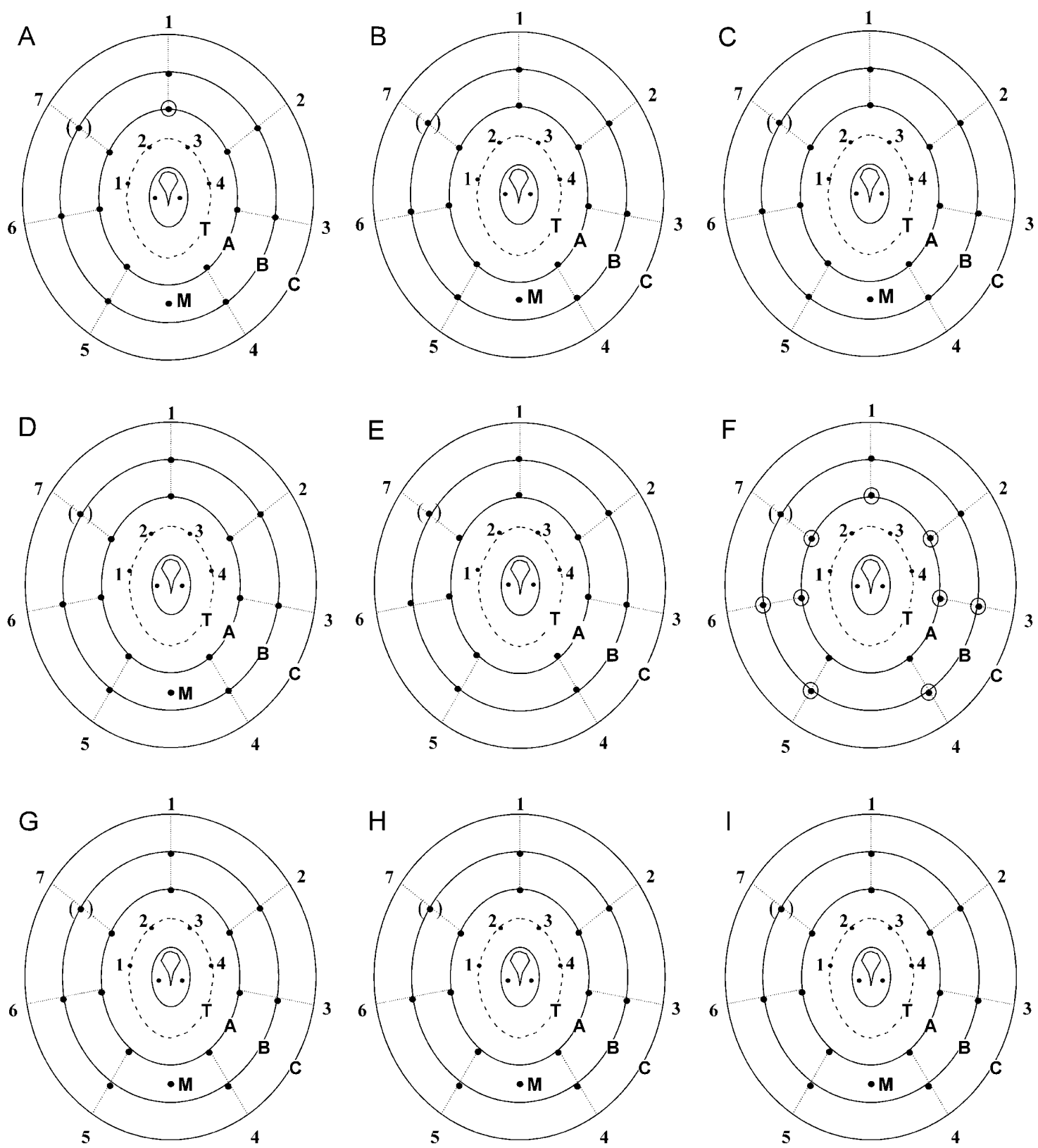

Fig. 12. Tibotarsal chaetotaxy. A - Brachystomella parvula (Brachystomellidae); B - Anurida granaria (Neanuridae: Pseudachorutinae); C - Pseudachorutes palmiensis (Neanuridae: Pseudachorutinae); D - Pseudanurida sawayana (Neanuridae: Pseudachorutinae); E - Friesea truncata (Neanuridae: Frieseinae); F - Friesea jeanneli (Neanuridae: Frieseinae); G - Caputanurina turbator (Neanuridae: Caputanurinae); H - Caledonimeria mirabilis (Neanuridae: Uchidanurinae); I - Neanura muscorum (Neanuridae: Neanurinae). Notice the absence of row $\mathrm{C}$, seta $\mathrm{Y}$, and empodial appendage in every Brachystomellidae and Neanuridae and the absence of seta $\mathrm{M}$ in Frieseinae.

Tetrodontophorinae, Neelipleona, Symphypleona, and Entomobryomorpha;

2. The paired valves partially overlap the supra-anal valve; the supra-anal valve has an almost straight edge (Fig. 14B). These kinds of anal valves are present in Hypogastruridae, Brachystomellidae, Odontellidae, Neanuridae, and Tullbergiinae. However, in the latter family, the supra-anal valve has a slightly convex edge but is recovered by the two other valves.

Three distinct nomenclatures were proposed to name the setae of paired anal valves: one established for the genus Willemia (see Hüther, 1962), one for the subfamily Tullbergiinae (see Rusek, 1976), and the last one for the genus Onychiurus (Yoshii, 1996). Anal valve chaetotaxy in Poduromorpha is quite homogeneous and therefore it is easy to propose homologies between the 3 nomenclatures, and generalized it to all Poduromorpha (see Table 6). Generally $1+1$ setae $\mathrm{z}$ are present (there can be more in some Onychiurinae) or can be absent. In the same way, 3+3 setae hr are generally found, but some taxa have less. Lawrence (1978) proposed a nomenclature for the setae of the anal valves for Symphypleona (see also Yosii, 1969). It should be possible to establish 


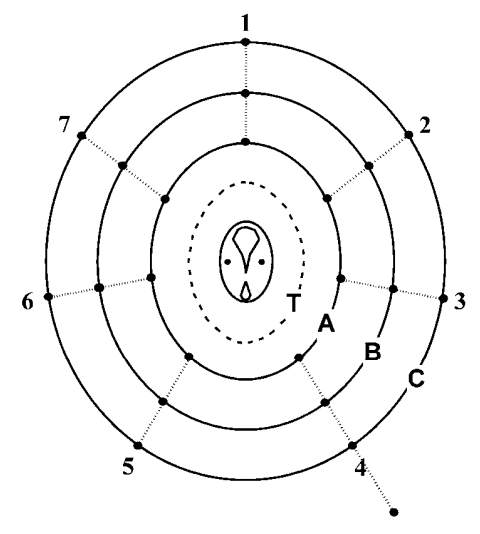

Fig. 13. Tibotarsal chaetotaxy of an Isotomidae (Folsomia candida) first instar.

homologies for the chaetotaxy of the anal valves of the four order of Collembola (Poduromorpha, Entomobryomorpha, Symphypleona, and Neelipleona). However, these comparisons are beyond the scope of the present work. Strong plurichaetoses can conceal the described chaetotaxic scheme (Tetrodontophora, Triacanthella...), making it difficult or impossible to establish homologies. This is also applicable to the chaetotaxy of the whole body.

Ventral tube. The ventral tube, or collophore, is formed by a pair of vesicles primitively derived from a pair of primitive appendages (the collophore is probably homologous to the coxae). The ventral tube is located on the sternum of the first abdominal segment, at the posterior end of the linea ventralis. It plays an important role in
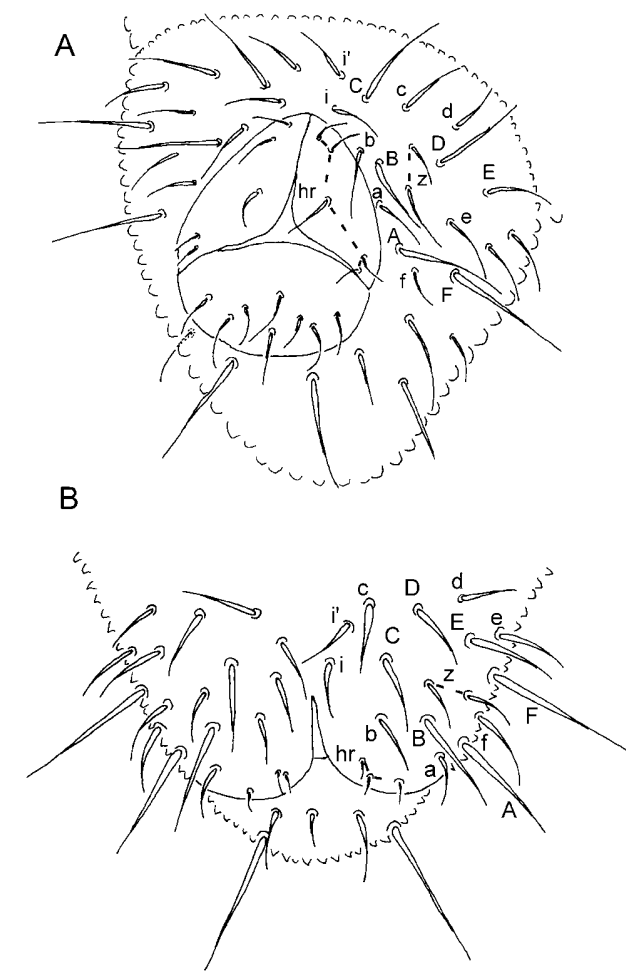

Fig. 14. Anal valves. A - Kalaphorura paradoxa (Onychiuridae: Onychiurinae); B - Friesea truncata (Neanuridae: Frieseinae).
TABLE 6. Correspondence between existing systems of nomenclature for setae of the anal valves.

\begin{tabular}{ccc}
\hline Hüther, 1962 & Rusek, 1976 & Yoshii, 1996 \\
\hline A & 110 & b-2 \\
a & 19 & b-1 \\
B & 15 & b-0 \\
b & 13 & b-1 \\
C & 12 & - \\
c & 11 & - \\
D & 17 & - \\
d & 111 & - \\
E & 112 & - \\
e & 114 & - \\
F & - & - \\
f & 113 & - \\
hr & 13, & a-1 \\
hr & 14 & a-0 \\
hr & 16 & a-1 \\
z & 18 & - \\
i & 13, & b-2 \\
i' & $12{ }^{\prime}$ & - \\
\hline
\end{tabular}

maintenance of water and ion balance. Urine is discharged from the labial nephridia (ventral side of the head) into the linea ventralis and carried to the ventral tube by capillary action (Eisenbeis, 1974; Rusek, 1987; Verhoef et al., 1979; Verhoef et al., 1983). Fluid and salt are then exchanged at the apical part of the organ (water is reabsorbed). The coronal section of the collophore is oval in Poduromorpha and circular in Symphypleona and Entomobryomorpha (Massoud, 1967). In other words, the ventral tube is a short oval-shaped structure in Poduromorpha, whereas it is a rather elongate cylinder in Symphypleona, Neelipleona, and Entomobryomorpha. Symphypleona have apical eversible vesicles on the ventral tube that can be smooth or covered with hemispherical papillae (Betsch, 1980).

In Hypogastruridae, Odontellidae, and Neanuridae, three kinds of ventral tube chaetotaxy are found (Deharveng, 1983):

1. $3+3$ setae: $\operatorname{td} 1, \mathrm{td} 2$, and $\mathrm{tp} 1$ in most Brachystomellidae and Odontellidae;

$24+4$ setae: $\operatorname{td} 1, \operatorname{td} 2, \operatorname{td} 3$ (sometimes $\operatorname{td} 4$ also), and tp 1 in Neanurinae, Caputanurinae, and Caledonimeria mirabilis Delamare Deboutteville \& Massoud, 1962;

3. 4+4 setae: $\mathrm{td} 1, \mathrm{td} 2, \mathrm{tp} 1$, and tp2 in Hypogastruridae, some Pseudachorutinae, Frieseinae, and Morulinae.

Tullbergiinae have the same ventral tube chaetotaxy as Hypogastruridae. Frequently in Onychiurinae plurichaetoses are observed: row td comprising more than $4+4$ setae, and row tp more than $2+2$ setae. Distal setae td are homologous with "subapical setae" described by Pomorski (1996) in Onychiurinae, and proximal setae tp are homologous with "additional setae".

Tenaculum and furcula. The tenaculum is located on the third abdominal sternum. It is formed of a corpus and 
two rami bearing a variable number of teeth on the outer side. The tenaculum holds the furcula against the abdomen. In Poduromorpha, the corpus is rudimentary, and does not bear setae unlike Symphypleona and Entomobryomorpha, which possess a well-developed corpus with setae.

Reductions of furcula and retinaculum are largely correlated.

Furcula is the jumping organ characteristic of Collembola. It can either be well developed as in the more epigeic species, reduced or completely absent (trend in the more edaphic species). From an evolutionary point of view, the furcula is probably the result of the partial merging of a pair of primitive appendages located on the sternum of the fourth abdominal segment. The fusion of the proximal region formed the manubrium; the distal portions remain free, forming the dentes, with each one ending with a mucro. The degree of development of the furcula, the number of setae on the manubrium and on the dentes, as well as the shape of the mucro are variable characters among the species and are widely used in taxonomy.

\section{REMARKS ON FIRST INSTAR}

Postembryonic development in Arthropleona always involves the addition of setae, never their loss (Deharveng, 1983; Thibaud, 1970). Therefore, the first instars are fundamental to understand structures that can be difficult to interpret in adults (Collazo, 2000), like, for example, in case of plurichaetosis (Szeptycki, 1972).

The first instar in the genus Onychiurus has relatively few setae, and its simple chaetotaxy appears to be very similar to the chaetotaxy of adult Hypogastruridae. A large number of setae appear when molting during postembryonic development. Pomorski (1996) described first instars of many species of Onychiurinae. Observations made on other species of the same sub-family for this study are in complete agreement with Pomorski's results.

Contrary to Onychiurinae, the first instar of Neanura muscorum has relatively complete chaetotaxy, which is almost identical with an adult one (labium, head, body, and all segments of the leg). However, some setae are not present in first instar, e.g. i' on the anal valves. The only present sensilla on the antennae are S5 and S6. Furthermore, in addition to present microsensillum, sensilla are always absent in first instar in the other Poduromorpha. Similar conclusions on chaetotaxy of the first instar were reached for Neanura tatricola Massoud, 1967 (Gruia, 1974) and Thaumanura ruffoi Dallai, 1969 (Dallai \& Martinozzi, 1980). This may be applicable to the entire sub-family Neanurinae. The first instar of Caputanurina turbator (the Caputanurinae are phylogenetically close to Neanurinae, D'Haese, 2003) was described (Najt \& Weiner, 1992). This group shows relatively complete chaetotaxy, but not as complete as in Neanurinae. For example, sensilla are absent on the fourth antennal segment in the first instar.
Thibaud has described the first instar of some species of Hypogastruridae, particularly in the genera Ceratophysella, Schaefferia, Mesogastrura Bonet, 1930, Mesachorutes Absolon, 1900, and Typhlogastrura Bonet, 1930 (Thibaud, 1967; Thibaud, 1969; Thibaud, 1970). Weiner (1989a) described the first instar of Ceratophysella mosquensis (Becker, 1910). These studies and observations made for the present work indicate that the first instar chaetotaxy of a Hypogastruridae is more complete than in Onychiurinae and less so in Neanuridae. In Hypogastruridae, the trochanters, femurs, and tibiotarsi of first instar present the same chaetotaxy as the adults. On the contrary, the proximal segments show an incomplete chaetotaxy. The same results were found for Tullbergiinae confirming observations on Mesaphorura and Fissuraphorura Rusek, 1991 (Luciáñez \& Simón, 1988; Luciáñez \& Simón, 1992; Rusek, 1980).

If one confronts the observations on the first instars to the phylogeny of Poduromorpha (D'Haese, 2002, 2003), some interesting conclusions can be drawn. From Onychiurinae to Neanurinae, the chaetotaxy is increasingly complete (compared to the adult) in the first instar. Tullbergiinae, Hypogastruridae and non-neanurinae Neanuridae are intermediate: the first instar chaetotaxy is more complete than that in Onychiurinae but less complete than in Neanurinae. However, the adults have chaetotaxic schemes increasingly paurochaetotic beginning with the Onychiurinae through Tullbergiinae and then Hypogastruridae to Neanurinae. There appears to be a trend in Poduromorpha, which drives the adult descendants to maintain a chaetotaxy similar to the juvenile instars of its ancestor without change of the growing rate and size. In other words, phenomenon of paedomorphosis by neoteny could have been among the driving forces at the origin of diversification within Poduromorpha.

ACKNOWLEDGEMENTS. I dedicate this study to J. Najt who accepted to be my advisor for my $\mathrm{PhD}$ and welcomed me in the CNRS ESA 8043, making the present work possible. I am most grateful to W. Weiner and J. Najt for inspiring discussions and support, and L. Deharveng and J. Palacios-Vargas for the specimens they provided. I specially thank L. Crowley for revising the English, A. Fjellberg and anonymous reviewer for their thorough comments and criticisms on the manuscript. Funding was obtained through CNRS ESA 8043 and French government MENRT PhD grant.

\section{REFERENCES}

Altner H. \& Thies G. 1976: The postantennal organ: a specialized unicellular sensory input to the protocerebrum in apterygoten insects (Collembola). Cell Tissue Res. 167: 97-110.

ANDRÉ H.M. 1988: The phanerotaxy of the genus Xenylla (Collembola: Hypogastruridae), with the description of a new species from Ethiopia. J. Afr. Zool. 102: 503-527.

Arbea J.I. \& Jordana R. 1986: Estudio del género Willemia en Navarra con especial referencia a la quetotaxia dorsal de la antena (Collembola: Hypogastruridae). Actas de las VIII Jornadas de la Asociación Española de Entomología. Asociación Española de Entomología, Sevilla, pp. 213-222.

ARLé R. \& Rufino E. 1976: Contribuição ao conhecimento dos Pseudachorutinae da Amazônia (Collembola). Acta Amazon. 6: 99-107. 
BabenKo A.B. 1997: The taxonomy and distribution of the genus Anurida (Collembola: Neanuridae) in the northern Palaearctic. Eur. J. Entomol. 94: 511-536.

BETSCH J.-M. 1980: Eléments pour une Monographie des Collemboles Symphypléones (Hexapodes, Aptérygotes). Mém. Mus. Natn. Hist. Nat. 116: 1-227.

BiTSCH C. \& BitsCH J. 1998: Internal anatomy and phylogenetic relationships among apterygote insect clades (Hexapoda). Annls Soc. Entomol. Fr. (N.S.) 34: 339-363.

BÖRNER C. 1901: Über ein neues Achorutidengenus Willemia, sowie 4 weitere neue collembolenformen derselben familie. Zool. Anz. 24: 428-432.

Börner C. 1906: Das system der Collembolen, nebst beschreibung neuer Collembolen des Hamburger naturhistorischen museums. Mitt. Nat. Mus., Hamburg 23: 147-188.

BÖRNER C. 1908: Collembolan aus Südafrika nebst einer studie über die I. Maxille der Collembolen. Denkschr. Med.-Naturw. Ges. Jena 13: 51-68.

Börner C. 1913: Die Familien der Collembolen. Zool. Anz. 41 315-322.

Bourlet A. 1839: Mémoire sur les Podurelles. Mem. Soc. R. Douai, $78 \mathrm{pp}$

BOUTHIER A. \& ThiBAUd J.-M. 1974: Recherches sur la pigmentation ommochromique des Insectes Collemboles en relation avec leur biotope. Pedobiologia 14: 103-105.

Cassagnau P. 1974: Chétotaxie et phylogénie chez les Collemboles Poduromorphes. Pedobiologia 14: 300-312.

Cassagnau P. 1980: Nouveaux critères pour un redécoupage phylogénétique des Collemboles Neanurinae (s. Massoud 1967). In Dallai R. (ed.): First Seminar on Apterygota. University of Siena, Siena, pp. 115-132.

Cassagnau P. 1990: Des Hexapodes vieux de 400 millions d'années: les Collemboles. I. Biologie et évolution. Année Biol. 29: 1-37.

Cassagnau P. \& Deharveng L. 1984: Collemboles des Philippines. I - Les Lobelliens multicolores des montagnes de Luzon. Trav. Lab. Ecobiol. Arthrop. Edaph. Toulouse 5: $1-11$.

Cassagnau P. \& Lauga-Reyrel F. 1984: L'architecture cuticulaire des Collemboles Neanurinae: présence d'un endosquelette superficiel chez certains d'entre eux. C. R. Acad. Sci. Paris 299: 591-596.

Chen B., SNIDER R.J. \& SNider R.M. 1997: Mouthparts of three collembolan species: comparative morphology. Invertebr. Biol. 116: 355-362.

Christian E. 1989: Position, structure, and systematic significance of anal valve pseudocelli in Onychiurid Collembola. In Dallai R. (ed.): Third International Seminar on Apterygota. University of Siena, Siena, pp. 43-46.

Christiansen K.A. 1965: Behavior and form in the evolution of cave Collembola. Evolution 19: 529-537.

Collazo A. 2000: Developmental variation, homology, and the pharyngula stage. Syst. Biol. 49: 3-18.

DA Gama M.M. 1964: Colêmbolos de Portugal Continental. Mem. Estud. Mus. Zool. Univ. Coimbra 292: 1-252.

DallaI R. 1971: First data ont the ultrastructure of the postantennal organ of Collembola. Rev. Ecol. Biol. Sol 8: 11-29.

DallaI R. 1973: Richerche sui Collemboli. XVIII. La cuticola e gli gnatiti di Tetrodontophora bielanensis (Waga) al microscopio eletronico a scansione. Redia 54: 105-116.

Dallai R. \& Martinozzi I. 1980: Ricerche sui Collemboli. XXV. La Val di Farma. Atti Acad. Fisiocrit. 12: 1-51.

De Geer C. 1743: Beskrifning påen Insect, kallad: Podura fusca, globosa, nitida, antennis longis articulus plurimis. K. Svenska Vetensk. Handl. 4: 296-305.
Deharveng L. 1978: Note sur un type d'organites tégumentaires originaux rencontré chez les Isotomides (Collembola). In: Dallai R. (ed): First International Seminary on Apterygota. Accademia delle Scienze di Siena detta de' Fisiocritici, Siena, pp. 59-62.

Demarveng L. 1979a: Chétotaxie sensillaire et phylogénèse chez les Collemboles Arthropleona. Trav. Lab. Ecobiol. Arthrop. Edaph. Toulouse 1: 1-15.

Deharveng L. 1979b: Contribution à la connaissance des Collemboles Neanurinae de France et de la péninsule Ibérique. Trav. Lab. Ecobiol. Arthrop. Edaph. Toulouse 1: 1-61.

Deharveng L. 1981a: La chétotaxie dorsale de l'antenne et son intérêt phylogénétique chez les Collemboles Neanuridae. Nouv. Rev. Entomol. 11: 3-13.

Deharveng L. 1981b: La famille des Odontellidae: phylogénèse et taxonomie. Trav. Lab. Ecobiol. Arthrop. Edaph. Toulouse 3: $1-21$.

Deharveng L. 1983: Morphologie évolutive des Collemboles Neanurinae en particulier de la lignée Néanurienne. Trav. Lab. Ecobiol. Arthrop. Edaph. Toulouse 4: 1-63.

DeHARveng L. 1987: Révision taxonomique du genre Tetracanthella Schött, 1891. Trav. Lab. Ecobiol. Arthrop. Edaph. Toulouse 5: 1-151.

Deharveng L. \& Bedos A. 1991: Taxonomy and cladistic analysis of the Thai species of Friesea Dalla Torre 1895 (Collembola: Neanuridae). Trop. Zool. 4: 287-315.

DenIs J.R. 1926: Notes sur les Aptérygotes. Sur l'organe postantennaire des Collemboles. Bull. Soc. Zool. Fr. 51: 241-244.

DenIs J.R. 1949: Sous-classe des Aptérygotes. In Grassé P.P. (ed.): Traité de Zoologie. Masson, Paris, pp. 111-275.

D'HAESE C. 1998: Willemia anophthalma-group (Collembola: Hypogastruridae): Systematics, new species, distribution and habitats. Eur. J. Entomol. 95: 581-592.

D'HAESE C. 2000: Is psammophily an evolutionary dead end? A phylogenetic test in the genus Willemia (Collembola: Hypogastruridae). Cladistics 16: 255-273.

D'HAEse C. \& Weiner W.M. 1998: A review of Willemia buddenbrocki-group (Collembola, Poduromorpha, Hypogastruridae) with cladistic analysis. J. Nat. Hist. 32: 969-986.

D'HAESE C.A. 2002: Were the first springtails semi-aquatic? A phylogenetic approach by means of $28 \mathrm{~S}$ rDNA and Optimization Alignment. Proc. R. Soc. Lond. (B) 269: 1143-1151.

D'HaEse C.A. 2003: Morphological appraisal of Collembola phylogeny with special emphasis on Poduromorpha and a test of the aquatic origin hypothesis. Zool. Scr. 32: 563-586.

DUNGer W. 1976: Taxonomische beitrage zur unterfamilie Onychiurinae Bagnall 1935 (Collembola). Abh. Ber. Naturkundemus. Görlitz 50: 1-16.

Edgecombe G.D., Wilson G.D.F., Colgan D.J., Gray M.R. \& Gerasimos C. 2000: Arthropod cladistics: Combined analysis of histone $\mathrm{H} 3$ and U2 snRNA sequences and morphology. Cladistics 16: 155-203.

EISENBEIS G. 1974: Licht- und elektronenmikroskopische Untersuchungen zur Ultrastruktur des Transportepithels am Ventraltubus arthropleoner Collembolen (Insecta). Cytobiology 9: $180-202$.

FJellberg A. 1984a: The maxillary outer lobe, an important systematic tool in Isotomidae (Collembola). Annls Soc. R. Zool. Belg. 114: 83-88.

FJellBerG A. 1984b: Maxillary structures in Hypogastruridae (Collembola). Annls Soc. R. Zool. Belg. 114: 89-99.

Fuellberg A. 1985a: Arctic Collembola I - Alaskan Collembola of the families Poduridae, Hypogastruridae, Odontellidae, Brachystomellidae and Neanuridae. Entomol. Scand. (Sup.) 21: 1-126. 
FJELlBERG A. 1985b: Elements of dorsal chaetotaxy in Neanuridae with descriptions of two new species of Anurida (Collembola). Entomol. Scand. 15: 349-362.

FJellberg A. 1991a: Tibiotarsal chaetotaxy in Tullbergiinae (Collembola: Onychiuridae). Entomol. Scand. 21: 431-434.

FJELlBERG A. 1991b: Tibiotarsal chaetotaxy in Willemia Börner, with description of a new species from North America (Collembola: Hypogastruridae). Entomol. Scand. 22: 205-207.

FJellberg A. 1994: The Collembola of the Norwegian Arctic Islands. Meddr Norsk Polarinst. 133: 1-57.

FJELlberg A. 1995: The systematic position of the monotypic family Isotogastruridae (Collembola) with description of Isotogastrura coronata n.sp. from Fuerteventura, Canary Islands. Miscnea Zool. 17: 123-127.

FJellberg A. 1999: The labial palp in Collembola. Zool. Anz. 237: 309-330.

Folsom J.W. 1899: The anatomy and physiology of the mouth parts of the Collembolan Orchesella cincta L. Bull. Mus. Comp. Anat. Harvard 35: 7-39.

Folsom J.W. 1900: The developement of the mouth parts of Anurida maritima Guér. Bull. Mus. Comp. Anat. Harvard 36: $87-157$.

Folsom J.W. 1932: Hawaiian Collembola. Proc. Hawaii. Entomol. Soc. 8: $51-92$

FrancoIs J. 1969: Anatomie et morphologie céphalique des Protoures (Insecta: Apterygota). Mém. Mus. Natn. Hist. Nat. (A) 59: 1-144

Geoffroy Saint-Hilaire E. 1818: Philosophie Anatomique. Vol. 1. Des Organes Respiratoires sous le Rapport de la Détermination et de l'Identité de leurs Pièces Osseuses. Baillière, Paris, $481 \mathrm{pp}$

Gisin H. 1952: Note sur les Collemboles, avec démembrement des Onychiurus armatus, ambulans et fimetarius Auct. Mitt. Schweiz. Entomol. Gesel. 25: 1-22.

GISIN H. 1960: Collembolenfauna Europas. Muséum d'Histoire Naturelle, Genève, $312 \mathrm{pp}$.

Gото H.E. 1972: On the structure and function of the mouthparts of the soil-inhabiting collembolan Folsomia candida. Biol. J. Linn. Soc. 4: 147-168.

Greenslade P.J.M. \& Deharveng L. 1997: Revision of Friesea species (Collembola: Neanuridae) of Australia and offshore islands, with biogeographical notes and key to species. Invert. Taxon. 11: 321-331.

Grow A.B. \& Christiansen K.A. 1974: Chaetotaxy in neartic Friesea (Collembola: Neanurinae) with notes on taxonomic use of chaetotaxy. Rev. Ecol. Biol. Sol. 11: 377-396.

Gruia M. 1974: Quelques observations morphologiques sur le développement de Neanura tatricola (Insecta: Apterygota, Collembola). Pedobiologia 14: 213-220

Guthrie J.E. 1906: Studies of the Colembolan eyes. Proc. Iowa Acad. Sci. 13: 239-243.

Hale W.G. \& SMith A.L. 1966: Scanning electron microscope studies of cuticular structures in the genus Onychiurus (Collembola). Rev. Ecol. Biol. Sol. 3: 343-354.

Haupt J. 1979: Phylogenetic aspects of recent studies on myriapod sense organs. In Camatini M. (ed.): Myriapod Biology. Academic Press, London, pp. 391-406.

Hopkin S.P. 1997: Biology of the Springtails (Insecta: Collembola). Oxford University Press, New York, $330 \mathrm{pp}$.

HopKIN S.P. 1998: Collembola: the most abundant insects on earth. Antenna 22: 117-121.

HÜTHER W. 1962: Beitrag zur Gattung Willemia Börner (Collembola). Beitr. Entomol. 12: 511-526.
Jordana R., Arbea J.I., Simón C. \& Luciáñez M.J. 1997: Collembola, Poduromorpha. Museo Nacional de Ciencias Naturales, CSIC, Madrid, $807 \mathrm{pp}$.

JURA C. 1967: The significance and function of the primary dorsal organ in embryonic development of Tetrodontophora bielanensis (Waga) (Collembola). Acta Biol. Cracov. 10: 301-311.

JurA C. \& KRZYSZToFowicz A. 1978: Ultrastructural changes in embryonic midgut cells developing into larval midgut epithelium of Tetrodontophora bielanensis (Waga) Collembola. Rev. Ecol. Biol. Sol. 14: 103-115.

KARUHIZE G.R. 1971: The structure of the postantennal organ in Onychiurus sp. (Insecta: Collembola) and its connection to the central nervous system. Z. Zellforsch. Mikrosk. Anat. 118: 263-282.

KONCEK F. 1924: Über autohaemorrohoe bei Tetrodontophora gigas Reuter. Zool. Anz. 61: 238-242.

LAWRENCE P.N. 1977: Studies on the tibiotarsal chaetotaxy of Collembola. Syst. Entomol. 2: 313-317.

LAWRENCE P.N. 1978: The terminology of terminalia and cartography of chaetotaxy in the Collembola, its evolutionary significance and systematic utility. In Dallai R. (ed.): First International Seminar on Apterygota. Accademia delle Scienze di Siena detta de' Fisiocritici, Siena, pp. 69-80.

LAWRENCE P.N. \& Massoud Z. 1974: Cuticule structures in the Collembola (Insecta). Rev. Ecol. Biol. Sol. 10: 77-101.

Lee B.-H. \& Thibaud J.-M. 1987: A critical review of the taxonomy of Gulgastrura reticulosa (Collembola: Hypogastruridae), a cave springtail from Korea. Syst. Entomol. 12: 73-79.

LuBBock J. 1873: Monograph of the Collembola and Thysanura. Ray Society, London, $276 \mathrm{pp}$.

LuCiáÑEZ M.J. \& Simón J.C. 1988: Morfología de los estados juveniles en Mesaphorura macrocheta (Collembola: Tullbergiinae). Actas III Congr. Ibér. Entomol. Universidad de Granada, Granada, pp. 115-120.

LuCí́Ñ̃ez M.J. \& Simón J.C. 1992: Evolución de la quetotaxia en Fissuraphorura gisini (Collembola: Tullbergiinae). Redia 75: $157-167$.

Lưcí́Ñez M.J. \& Simón J.C. 1993: Filogenia de los Tullbergiinae Bagnall, 1935 de la península Ibérica (Collembola: Onychiuridae). Nouv. Rev. Entomol. 10: 187-200.

MARI Mutt J.A. 1988: A new Dicranocentrus from Thailand, redescription of D. fasciatus Yosii and records for two other species of Orchesellinae (Collembola: Entomobryidae. $J$. Kansas Entomol. Soc. 61: 179-185.

Massoud Z. 1967: Monographie des Neanuridae, Collemboles Poduromorphes à Pièces Buccales Modifiées. In Delamare Deboutteville C. \& Rapoport E.H. (eds): Biologie de l'Amérique Australe. CNRS, Paris, pp. 7-399.

Massoun Z. 1969: Etude de l'ornementation épicuticulaire du tégument des Collemboles au microscope électronique à balayage. C. R. Acad. Sci. Paris 268: 1407-1409.

MAssoud Z. 1971a: Contribution à la connaissance morphologique et systématique des Collemboles Neelidae. Rev. Ecol. Biol. Sol. 8: 195-198.

MAssoun Z. 1971b: Un élément caractéristique de la pédofaune: les Collemboles. In Pesson P. (ed.): La Vie dans les Sols. Aspects nouveaux. Etudes expérimentales. Gauthier-Villars, Paris, pp. 337-388.

MASSOUd Z. \& BARRA J.-A. 1980: Interprétation ultrastructurale de la microsculpture epicuticulaire des Collemboles Entomobryomorphes (Aptérygotes). Rev. Ecol. Biol. Sol. 17: 251-260.

Massoud Z. \& B B̈sCh J.-M. 1973: Existence d'un troisième niveau d'organisation de l'ornementation épicuticulaire chez 
le Collembola Tetrodontophora Reuter, 1882. C. R. Acad. Sci. Paris 276: 989-990.

Massoud Z. \& ElLis W.N. 1977: Proposition pour une classification et une nomenclature cohérente des phanères des Collemboles européens. Rev. Ecol. Biol. Sol. 14: 163-179.

Massoud Z. \& ThiBaud J.-M. 1979: Discussion sur l'hétérogénéité de l'ornementation épicuticulaire chez les Xenylla (Collemboles, Hypogastruridae). Rev. Ecol. Biol. Sol. 16: $535-539$.

Massoud Z., Nart J. \& Thibaud J.-M. 1975: Description d'un nouveau genre de Collembola de la Jamaïque. Considérations sur le labium des Arthropléones. Nouv. Rev. Entomol. 5: $111-117$

Mendoça M.C. \& Fernandes L.H. 1999: Contribuição para o conhecimento do gênero Arlesia Handschin (Collembola, Neanuridae, Pseudachorutinae). Revta Bras. Zool. 16: 1195-1201.

MoEn P. \& Ellis W.N. 1984: Morphology and taxonomic position of Podura aquatica (Collembola). Entomol. Gen. 9: 193-204.

NAJT J. 1977: Un nouveau genre de Collembola Isotomidae du Népal: Jestella siva n. g. n. sp. Nouv. Rev. Entomol. 7: 363-375.

NAJT J. \& Rưbio I. 1978: Tullbergiinae Sud-Américaines. I. Le genre Dinaphorura (Coll.). Nouv. Rev. Entomol. 2: 95-112.

NAJT J. \& WEINER W.M. 1992: Koreanurina new genus, Leenurina new genus and Caputanurina Lee, 1983 (Collembola: Neanuridae) from North Korea. Pan-Pac. Entomol. 68 : 200-215.

NAJT J. \& Weiner W.M. 2002: A new genus Pongeia from France, without mandibles: why does not belong to Brachystomellidae (Collembola)? Acta Zool. Cracov. 45: 337-340.

NAYrolles P. 1988: Chétotaxie tibiotarsale des Collemboles Symphypléones. Trav. Lab. Ecobiol. Arthrop. Edaph. Toulouse 5: 1-19.

NaYrolles P. 1991: La chétotaxie antennaire des Collemboles Symphypléones. Trav. Lab. Ecobiol. Arthrop. Edaph. Toulouse 6: 1-94.

NAYROLles P. 1998: Analysis of a species-instar-characters table: a theoretical survey on the use of chaetotaxy in ontophylogenetic studies. Contrib. Zool. 67: 197-220.

Nayrolles P. \& Betsch J.-M. 1993: Pour une théorie de la description chétotaxique chez les Collemboles. Annls Soc. ent. Fr. (N.S.) 29: 5-15.

PaClt J. 1956: Biologie der Primär Flügellosen Insekten. Gustav Fischer Verlag, Jena, 258 pp.

Philiptschenko J. 1912: Beiträge zur Kenntnis der Apterygoten III. Die Embryonalent wicklung von Isotoma cinerea Nic. Z. Wiss Zool. 103: 519-660.

Pomorski R.J. 1990: New data on the genus Hymenaphorura (Collembola: Onychiuridae) from Europe. Mitt. Schweiz. Entomol. Ges. 63: 209-225.

PoMORSKI R.J. 1996: The first instar larvae of Onychiurinae - a systematic study (Collembola: Onychiuridae). Genus 7: $1-102$.

POMORSKI R.J. 1998: Onychiurinae of Poland (Collembola: Onychiuridae). Polish Taxonomical Society, Wrocklaw, $201 \mathrm{pp}$.

PoMorsKi R.J. \& SKarżyńsKi D. 1992: Collembola Polski. Biologica Silesiae, Warsaw, 80 pp.

Potapov M.B. 1994: Genus Willemia. In Chernova N.M. (ed.) Collembola of Russia and Adjacent Countries: Family Hypogastruridae. Nauka, Moscow, pp. 232-250.

RAPOPORT E.H. 1969: Gloger's rule and pigmentation of Collembola. Evolution 23: 622-626.
RAPOPORT E.H. 1971: The geographical distribution of Neotropical and Antarctic Collembola. Pacif. Insects Monogr. 25: 99-118.

RUSEK J. 1976: New Onychiuridae (Collembola) from Vancouver Island. Can. J. Zool. 54: 19-41.

RUSEK J. 1980: Morphology of juvenile instars in two Mesaphorura species (Collembola: Tullbergiinae). Rev. Ecol. Biol. Sol. 17: $583-589$.

RUSEK J. 1984: A new location and type of pseudocelli in Onychiurus spp. (Collembola: Onychiuridae). Annls Soc. R. Zool. Belg. 114: 3-7.

RuseK J. 1987: New types of linea ventralis in Collembola and its function. In Striganova B.R. (ed.): Soil Fauna and Soil Fertility. Nauka, Moscow, pp. 699-706.

RUSEK J. 1998: Biodiversity of Collembola and their functional role in the ecosystem. Biodivers. Conserv. 7: 1207-1219.

RUSEK J. \& WEYDA F. 1981: Morphology, ultrastructure and function of pseudocelli in Onychiurus armatus (Collembola: Onychiuridae). Rev. Ecol. Biol. Sol. 18: 127-133.

SALMON J.T. 1964: An index to the Collembola. I. R. Soc. New Zealand Bull. 7: 1-144.

StaCh J. 1949: The Apterygotan Fauna of Poland in Relation to the World-Fauna of this Group of Insects: Families Neogastruridae and Brachystomellidae. Acta Monographica Musei Historiae Naturalis, Krakow, 341 pp.

SтACH J. 1951: The Apterygotan Fauna of Poland in Relation to the World-Fauna of this Group of Insects: Family Bilobidae. Acta Monographica Musei Historiae Naturalis, Krakow, 97 pp.

SteBaeva S.K. 1988: Systematic position and phylogeny. In Tzernova N.M. \& Striganova B.R. (eds): Manuel d'Identification des Collemboles d'URSS: Partie Générale, Clés des Familles et des Genres. Nauka, Moscow, pp. 5-9.

SZEPTYCKI A. 1972: Morpho-systematic studies on Collembola. III. Body chaetotaxy in the first instars of several genera of the Entomobryomorpha. Acta Zool. Cracov. 17: 341-372.

SzEPTYCKI A. 1977: Morpho-systematic studies on Collembola. V. The body chaetotaxy of the genera Oncopodura Carl et Lebedinsky, 1905 and Harlomillsia Bonet, 1944. (Oncopoduridae). Rev. Ecol. Biol. Sol. 14: 199-209.

TAmarelle M. 1971: Principales étapes du développement embryonnaire chez le Collembola Anurida maritima Guér. Rev. Ecol. Biol. Sol. 8: 159-162.

TAMARelle M. 1981: La formation et l'évolution de l'organe dorsal chez les embryons de cinq Collemboles (Insecta: Apterygota). Int. J. Insect Morph. Embryol. 8: 95-111.

Thibaud J.-M. 1967: Contribution à l'étude du développement postembryonnaire chez les Collemboles Hypogastruridae épigés et cavernicoles (première note). Annls Spéléol. 22: $167-197$.

Thibaud J.-M. 1969: Contribution à l'étude du développement postembryonnaire chez les Collemboles Hypogastruridae épigés et cavernicoles (suite). Rev. Ecol. Biol. Sol. 6: 209-220.

Thibaud J.-M. 1970: Biologie et écologie des Collemboles Hypogastruridae édaphiques et cavernicoles. Mém. Mus. Natn. Hist. Nat. (A) 61: 83-201.

Thrbaud J.-M. 1976: Structure et régression de l'appareil oculaire chez les Insectes Collemboles. Rev. Ecol. Biol. Sol. 13: $173-190$.

Thrbaud J.-M. \& Massoud Z. 1973: Etude de la régression des cornéules chez les Insectes Collemboles. Annls Spéléol. 28: $159-166$.

ThIEGS O.W. 1942: The dorsal organ of Collembola embryos. Quart. J. Micr. Sci. 83: 153-167. 
TUXEN S.L. 1959: The phylogenetic significance of entognathy in entognathous Apterygotes. Smithson. Contr. Zool. 137 $379-416$.

UCHIDA H. 1971: Tentative key to the japanese genera of Collembola in relation to the world genera of this order I. Sci. Rep. Hirosaki Univ. 18: 64-76.

Usher M.B. \& BAlogun R.A. 1966: A defense mechanism in Onychiurus (Collembola: Onychiuridae). Entomol. Mon. Mag. 102: 237-238.

Verhoef H.A., Bosman C., Bierenbroodspot A. \& Boer H.H. 1979: Ultrastructure and function of the labial nephridia and the rectum of Orchesella cincta (L.) (Collembola). Cell Tissue Res. 198: 237-246.

Verhoef H.A., Witteveen J., Van Der Woude H.A. \& Joosse E.N.G. 1983: Morphology and function of the ventral groove of Collembola. Pedobiologia 25: 3-9.

Verhoef H.A., Verspagen J.M.H. \& ZoOmer H.R. 2000: Direct and indirect effects of ultraviolet-B radiation on soil biota, decomposition and nutrient fluxes in dune grassland soil systems. Biol. Fert. Soils 31: 366-371.

WENER W.M. 1989a: Morphological changes during postembryonal development in Ceratophysella armata (Gisin, 1949). In Dallai R. (ed.): Third International Seminar on Apterygota. University of Siena, Siena, pp. 47-53.

WeINER W.M. 1989b: Onychiurinae (Onychiuridae, Collembola) of North Korea: species of the Paronychiurus flavescens (Kinoshita, 1916) group. Acta Zool. Cracov. 32: 85-92.

WENER W.M. 1996: Generic revision of Onychiurinae (Collembola: Onychiuridae) with a cladistic analysis. Annls Soc. Entomol. Fr. (N.S.) 32: 163-200.

WEINER W.M. \& FJELlberG A. 1994: Redescription and lectotype designation of Hymenaphorura sibirica (Tullberg, 1876) (Collembola: Onychiuridae). Entomol. Scand. 25: 415-417.

WeIneR W.M. \& NaJt J. 1991a: Collembola Poduromorpha of South Africa. Bonn. Zool. Beitr. 42: 369-387.
Weiner W.M. \& NaJt J. 1991b: Collemboles Poduromorpha de Nouvelle-Calédonie. 6. Onychiuridae Tullbergiinae. In Chazeau J. \& Tillier S. (eds): Zoologia Neocaledonica. Mémoires du Muséum National d'Histoire Naturelle, Paris, pp. 119-130

Weiner W.M. \& NaJT J. 2000: New North Korean species of Psyllaphorura Bagnall, 1948 (Collembola: Onychiuridae). Contr. Biol. Lab. Kyoto Univ. 29: 133-137.

WHEELER W.M. 1893: A contribution to insect embryology. $J$. Morphol. 8: 1-160.

Willem V. 1900: Recherche sur les Collemboles et les Thysanoures. Mém. Cour. Sav. Etr. Acad. R. Sci. Belg. 58: 1-144.

YoshiI R. 1996: Identity of some japanese Collembola IV. "Deuteraphorura" group of Onychiurus - continued. Ann. Spel. Japan (Iwaizumi) 14: 1-15.

Yosil R. 1956: Monographie zur Höhlencollembolen Japans. Contr. Biol. Lab. Kyoto Univ. 3: 1-109.

Yosi R. 1962: Studies on the Collembolan genus Hypogastrura II. Nearctic forms collected by Prof. F. Bonet. Contr. Biol. Lab. Kyoto Univ. 13: 1-25.

Yosil R. 1967: Studies on the Collembolan familly Tomoceridae, with special reference to Japanese forms. Contr. Biol. Lab. Kyoto Univ. 20: 1-54.

Yosil R. 1969: Dicyrtoma \& Ptenothrix (Insecta: Collembola) of the Solomon Islands. Zool. J. Linn. Soc. 48: 217-236.

Yosil R. 1971: Collembola of Khumbu Himal, Khumbu Himal. Universitätsverlag Wagner, Innsbruck, München, pp. 80-130.

Yosil R. 1976: Structure and chaetotaxy of labrum as the taxonomic character of Collembola. Rev. Ecol. Biol. Sol. 13: 233-239.

ZinKLer D. \& Wilking K. 1989: Pigmentation in Collembola: an ecophysiological approach. In Dallai R. (ed.): Third International Seminar on Apterygota. University of Siena, Siena, pp. $467-475$.

Received November 12, 2002; revised April 14, 2003; accepted April 21, 2003 